\title{
Vascular Endothelial Growth Factor: A Translational View in Oral Non-Communicable Diseases
}

\author{
Sven Niklander ${ }^{1}$ (D), María José Bordagaray ${ }^{2,3}$, Alejandra Fernández ${ }^{2,4}$ and Marcela Hernández ${ }^{2,5, *}$ \\ 1 Unit of Oral Pathology and Medicine, Faculty of Dentistry, Universidad Andres Bello, \\ Viña del Mar 2520000, Chile; sven.niklander@unab.cl \\ 2 Laboratory of Periodontal Biology, Faculty of Dentistry, Universidad de Chile, Santiago 8380544, Chile; \\ mbordagaray@odontologia.uchile.cl (M.J.B.); alejandra.fernandez@unab.cl (A.F.) \\ 3 Department of Conservative Dentistry, Faculty of Dentistry, Universidad de Chile, Santiago 8380544, Chile \\ 4 Unit of Oral Pathology and Medicine, Faculty of Dentistry, Universidad Andres Bello, Santiago 8320000, Chile \\ 5 Department of Oral Pathology and Medicine, Faculty of Dentistry, Universidad de Chile, \\ Santiago 8380544, Chile \\ * Correspondence: mhernandezrios@odontologia.uchile.cl; Tel.: +56-929-781-833
}

Citation: Niklander, S.; Bordagaray, M.J.; Fernández, A.; Hernández, M. Vascular Endothelial Growth Factor: A Translational View in Oral Non-Communicable Diseases. Biomolecules 2021, 11, 85. https:// doi.org/10.3390/biom11010085

Received: 22 December 2020

Accepted: 8 January 2021

Published: 12 January 2021

Publisher's Note: MDPI stays neutral with regard to jurisdictional clai$\mathrm{ms}$ in published maps and institutional affiliations.

Copyright: $\odot 2021$ by the authors. Licensee MDPI, Basel, Switzerland. This article is an open access article distributed under the terms and conditions of the Creative Commons Attribution (CC BY) license (https:// creativecommons.org/licenses/by/ $4.0 /)$.

\begin{abstract}
Vascular endothelial growth factors (VEGFs) are vital regulators of angiogenesis that are expressed in response to soluble mediators, such as cytokines and growth factors. Their physiologic functions include blood vessel formation, regulation of vascular permeability, stem cell and monocyte/macrophage recruitment and maintenance of bone homeostasis and repair. In addition, angiogenesis plays a pivotal role in chronic pathologic conditions, such as tumorigenesis, inflammatory immune diseases and bone loss. According to their prevalence, morbidity and mortality, inflammatory diseases affecting periodontal tissues and oral cancer are relevant non-communicable diseases. Whereas oral squamous cell carcinoma (OSCC) is considered one of the most common cancers worldwide, destructive inflammatory periodontal diseases, on the other hand, are amongst the most prevalent chronic inflammatory conditions affecting humans and also represent the main cause of tooth loss in adults. In the recent years, while knowledge regarding the role of VEGF signaling in common oral diseases is expanding, new potential translational applications emerge. In the present narrative review we aim to explore the role of VEGF signaling in oral cancer and destructive periodontal inflammatory diseases, with emphasis in its translational applications as potential biomarkers and therapeutic targets.
\end{abstract}

Keywords: VEGF; VEGFR; angiogenesis; periodontitis; periimplantitis; apical periodontitis; oral cancer; oral squamous cell carcinoma

\section{Introduction}

Vasculogenesis, the formation of blood vessels from de novo generation of endothelial cells, and angiogenesis, the process of new blood vessel formation, are critical during development and physiologic homeostasis, but can also mediate the pathogenesis of several diseases. Vascular endothelial growth factors (VEGFs) are vital regulators of angiogenesis and vasculogenesis that are expressed in response to soluble mediators, such as cytokines and growth factors [1]. The physiologic functions of the VEGF signaling axis involve blood vessel formation-endothelial cell proliferation, migration, and cell survival-, regulation of vascular permeability and maintenance of bone homeostasis and repair, affecting the differentiation and function of osteoblasts and osteoclasts [2]. VEGF is also required for stem cell and monocyte/macrophage recruitment, maintenance of tissue barrier functions and neuroprotection [3]. In addition to these physiologic processes, angiogenesis plays a pivotal role in oral chronic pathologic conditions, such as tumorigenesis and inflammatoryimmune diseases with bone loss [3,4].

VEGF is a type of glycoprotein, which possesses angiogenic, mitogenic and vascular permeability regulating properties, thus enhancing the activity of endothelial cells. 
The VEGF family includes VEGF-A, -B, -C and -D, as well as placental growth factor, which interact differently with cell-surface tyrosine kinase receptors, VEGFR 1-3. Overall, they regulate blood vessel morphogenesis and permeability, though VEGF-C and VEGF-D are primarily implicated in regulation of lymphogenesis [2]. As the prototypical VEGF, VEGF-A is considered the most potent stimulator of vasculogenesis and angiogenesis. In addition to increase vascular permeability, vasodilatation, and the recruitment of inflammatory cells, VEGF triggers the inhibition of apoptosis and increases cellular proliferation. Binding of VEGFR to its ligands, considered to be the "canonical signaling", induces receptor homodimerization or heterodimerization, leading to activation of the tyrosine kinase and autophosphorylation of tyrosine residues in the receptor intracellular domains to initiate consecutive intracellular signaling pathways, including the PI3K and p38 MAPK pathways. This represents most probably the prevailing mechanism by which VEGF exerts its effects over proliferation, migration and vascular morphogenesis [5]. Alternatively, ligand-independent receptor activation or "non-canonical VEGF signaling" might be initiated i.e., by Src-mediated activation and downstream ligand-mediated transphosphorylation $[1,6]$.

VEGF receptors are located in endothelial cells, but also in many non-endothelial cells, and act through autocrine pathways to regulate cell survival and function. The VEGFR1 gene codifies for two variants of the VEGFR1 receptor: a full-length VEGFR1/Flt-1 receptor with tyrosine kinase mRNA form; and a soluble form carrying only the ligand-binding region (sFlt-1/soluble VEGFR1) that functions as a decoy receptor by trapping its ligands VEGF-A, PIGF, and VEGF-B. This way gene expression is regulated through the balance between its full-length and soluble forms. Downstream activation of diverse pathways including phospholipase $\mathrm{C}-\mathrm{x}$, protein kinase $\mathrm{C}, \mathrm{Ca}^{2+}$, extracellular-signal-regulated protein kinase (ERK), Akt, Src, focal adhesion kinase and calcineurin have been implicated in mediating the multiple VEGF functions [5]. Moreover, there is a strong crosstalk between cell responses to hypoxia, cancer and inflammation. Both diseases create hypoxic conditions at the local site due to increased metabolic activity outpacing the availability of oxygen. Hypoxia inducible factor (HIF) is a pivotal transcription factor induced under hypoxia that transactivates target genes, including VEGF, and has a direct effect on the master switch of inflammation, nuclear factor (NF)- $\mathrm{KB}$ pathway.

Accordingly, the coordinated output from these signaling systems controls angiogenesis, blood flow, tissue perfusion, inflammatory cell extravasation, and bone remodeling and repair $[2,3]$. Herein, we aim to explore the role of VEGF signaling in oral cancer and destructive periodontal inflammatory diseases, with emphasis in its translational applications as potential biomarkers and therapeutic targets. For this purpose, we analyzed the available literature using the following MESH terms: "VEGF", "periodontitis", "periImplantitis", "periapical periodontitis" and "mouth neoplasm". The studies used for this review included analytical and interventional original research articles and systematic reviews with or without meta-analysis available in English with focus on the last 10 years.

\section{Oral Cancer}

Oral cancer is considered one of the most common cancers worldwide with a global incidence of more than 350,000 new cases and 177,000 deaths every year, with considerable geographic variations [7]. Ninety percent of all oral cancers are oral squamous cell carcinomas (OSCC), the most common form of oral cancer. The remaining $10 \%$ consist of salivary gland cancers, lymphomas, sarcomas and metastasis [8]. The overall survival rate of oral cancer is $\approx 50 \%$ during the first 5 years [9], mainly because most cases are diagnosed at advanced stages of the disease (stages III or IV) [10]. Many OSCCs develop from oral potentially malignant disorders (OPMDs) (lesions in which cancer is more likely to arise that can have different degrees of dysplasia), but only $5 \%$ of all OPMDs undergo malignant transformation [11].

Like normal tissues, tumors need nutrition, oxygenation and a system to evacuate metabolic wastes and carbon dioxide, which is granted by the tumor-associated neovascu- 
lature generated by the process of angiogenesis. Angiogenesis is considered a hallmark of cancer, as is essential for the growth, invasion and metastasis of tumors [12]. Neoplastic cells can only form a clinically observable tumor if the host is able to provide a vascular network. Tumors will not grow more than $1-2 \mathrm{~mm}$ in size unless an intra-tumoral capillary network is developed [13].

VEGF is probably the most essential angiogenic factor expressed in cancer, as it plays a central role in regulating angiogenesis in solid tumors [1]. Animal models have shown that rapid tumor growth and microvascular density (MVD) are directly associated with VEGF expression [14], which is associated with the angiogenic switch. The angiogenic switch reveals the capability of neoplastic and inflammatory cells to produce angiogenic factors into the tumor microenvironment to stimulate proliferation and migration of endothelial cells to form a newly vasculature that provides oxygen and nutrients to the tumor [15]. As mentioned early, VEGF also participates in the recruitment of inflammatory cells and inhibits endothelial cell apoptosis [16] which are important features for the maintenance of the tumor neovasculature. VEGF helps in the recruitment of different inflammatory cells by inducing the activation of cyclooxygenase 2 (COX-2), which leads to NF-kB activation with subsequent release of inflammatory cytokines such as IL-1 and TNF- $\alpha$, among others [17] (Figure 1). VEGF can inhibit endothelial cell apoptosis whether by inducing the expression of anti-apoptotic proteins, such as Bcl-2, survivin and A1, or by activating thePI3K/Akt pathway [18]. This promotes cell survival, by blocking the pro-apoptotic effects of BAD and Bax, and by inducing the expression of pro-survival genes (e.g., NF-kB) [19].

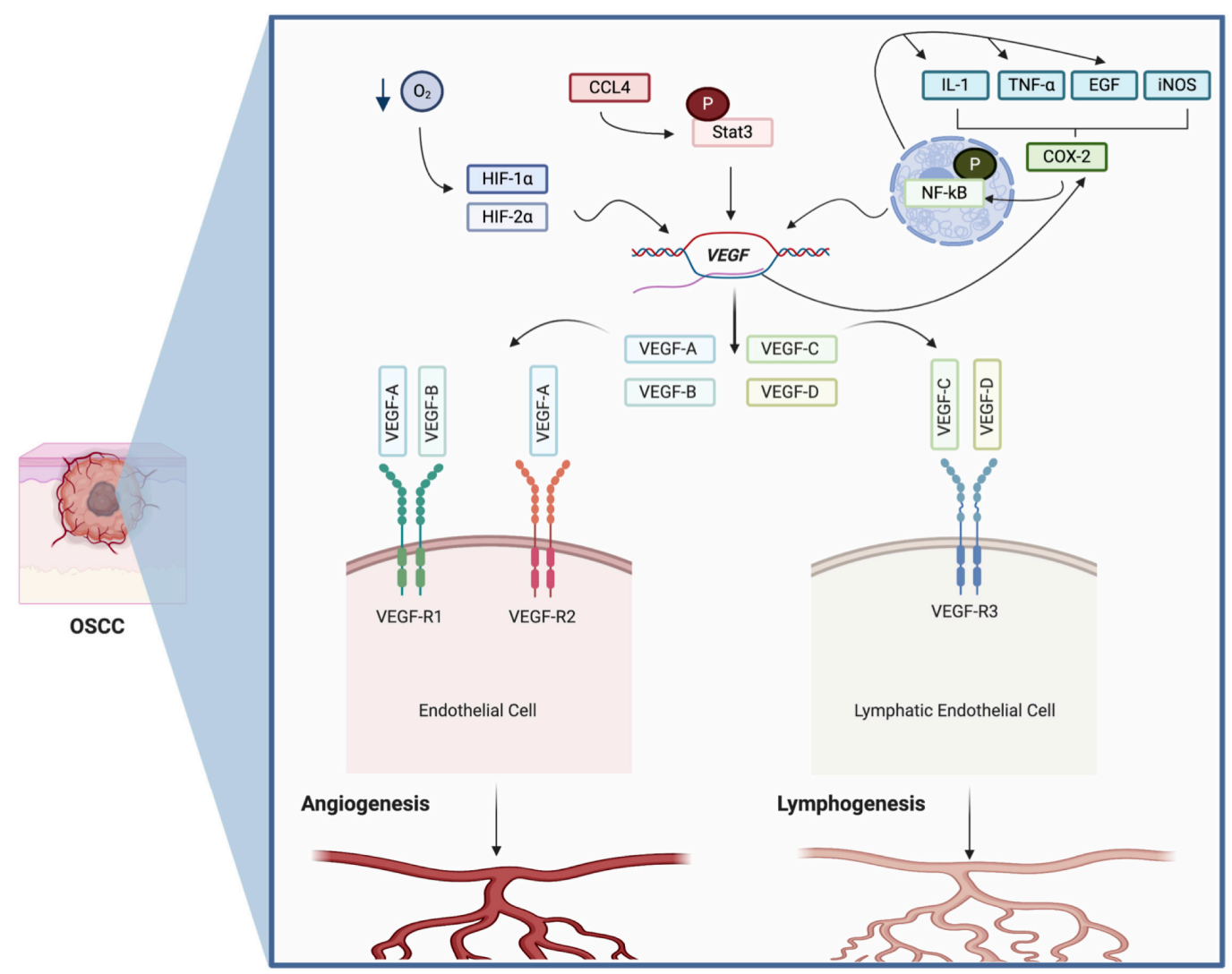

Figure 1. Role of VEGF signaling in OSCC. VEGF is constitutively expressed in oral squamous cell carcinoma. Its secretion can be the result of the activation of different signaling pathways, which includes: (1) the production of hypoxia inducible and HIF- $2 \alpha$ by low oxygen levels, (2) the activation of Stat3 by CCL4 (which is constitutively expressed in OSCC) and (3) the activation of COX2 by different inflammatory molecules (commonly overexpressed in OSCC) which activate the NF-kB pathway. The activation of these pathways leads to the transcription of all four variants of VEGF (A-D), which through the activation of VEGF-R1, VEGF-R2 and VEGF-3 on blood and lymphatic endothelial cells, induces angio- and lymphogenesis. Created with BioRender.com. 
Originally it was thought that angiogenesis was only important for the rapid growth of macroscopically detected tumors. Nevertheless, it was later demonstrated that angiogenesis also contributes to the premalignant phase of neoplastic progression [12], which is also the case in OPMDs. In normal oral mucosa (NOM) VEGF is not usually detected or observed only in up to $30 \%$ of NOM samples with classical immunohistochemistry techniques, usually confined to the basal and parabasal layers of the epithelium [20]. Sauter et al. were the first to demonstrate a gradual and progressive increase of VEGF expression during the whole process of oral carcinogenesis, with weak or absent staining in NOM, moderate staining in moderate dysplasia, carcinoma in situ and early primary OSCC, and intense staining in advanced primary and metastatic OSCC [14].

In OPMDs, VEGF is diffusely expressed across the epithelium in $63 \%$ to $100 \%$ of all studied samples [21], whereas in OSCC it is usually expressed in 100\% of the samples [22,23]. Mean MVD is also reported to be higher in OPMDs than in NOM [14,21] and has been positively correlated with the degree of dysplasia [15,21,24] and VEGF expression [20,25]. The degree of dysplasia has also been significantly correlated with VEGF and mast cell density (MCD) which are thought to be important for the initial stages of oral carcinogenesis as they contribute to angiogenesis [24].

There is robust evidence showing VEGF upregulation in oral cancer [14,21,24,26,27]. In OSCC, VEGF expression has been associated with tumor differentiation [26,28], clinical stage [29], nodal metastasis [21,30], distant metastasis [31] and overall survival [32]. Same as with oral dysplasia, mean MVD and MCD increase significantly in OSCC compared to NOM and have been associated with VEGF levels [24,25]. Mean MVD has also been positively associated with tumor size [30]. All VEGF family members (A-D) are expressed in OSCC. VEGF-A and VEGF-B are associated with angiogenesis, as their increase is correlated with an increase in mean MVD, whereas VEGF-C and VEGF-D are associated with lymph node involvement [33]. Expression of VEGF receptors (VEGFR1-3) has also been recently studied in OSCC. Using immunohistochemistry, it was found that $88 \%$ (44 out of 50 cases) of OSSC s overexpressed some form of VEGF-R. VEGFR-1 was overexpressed in $56 \%$ of the samples, VEGFR-2 in $42 \%$ and VEGFR-3 in $60 \%$, but many samples expressed a combination of more than one variant. More importantly, VEGFR expression was associated with clinical parameters, such as neck node involvement, tumor size and tumor associated death [34].

The VEGF gene is considered a highly polymorphic gene with multiple single nucleotide polymorphisms (SNPs) which have been related with OSCC development and progression. VEGF-C rs766413 and rs20446463 polymorphism have been linked with oral cancer susceptibility in a Taiwanese population [35]. VEGF-A + 936 CC polymorphism has been associated with advanced OSCC and VEGF-A -1154 GG genotype is considered as an independent adverse factor for survival of OSCC patients [36]. A recent systematic review concluded that VEGF + 936 CT or TT polymorphism may be associated with an increased risk of oral cancer among caucasians [37].

It is well known that VEGF production and tumor angiogenesis are regulated by the interaction of multiple molecules. The increase in VEGF expression in oral cancer might be a response to tumor-associated hypoxia, as in vivo and in vitro studies have shown VEGF upregulation in decreasing concentrations of oxygen [30,38]. Hypoxia-inducible factor- $1 \alpha(\mathrm{HIF}-1 \alpha)$ is a transcription factor usually upregulated under hypoxic conditions and cumulative genetic alterations. In OSCC cells, HIF-1 $\alpha$ expression is also regulated by the hepatoma-derived growth factor (HDGF), as its inhibition reduces HIF-1 $\alpha$ and VEGF expression [39]. HIF-1 $\alpha$ binds to hypoxia response elements and regulates changes in the expression of different factors, such as VEGF [40], plasminogen activator inhibitor-1 (PAI-1) and carbonic anhydrase 9 (CAIX) [28], promoting neovascularization and favoring tumor spread [41]. HIF-1 $\alpha$ and HIF-2 $\alpha$ have shown positive correlation with clinicalpathological parameters in OSCC, tumor size and MVD, and their knock down inhibited tumor angiogenesis and tumor growth in a nude mice xenograft model [42]. 
Although hypoxia contributes to the angiogenic switch, it is not the only mechanism involved. Signal transducers and activators of transcription 3 (Stat3) are considered an important regulator of VEGF expression in cancer. Stat3 regulates VEGF production through a putative Stat3 responsive element on the VEGF promoter, inducing VEGF mRNA transcription [43]. Stat3 is constitutively expressed in OSCC and its phosphorylation is associated with a more aggressive phenotype of the disease. An increase in its phosphorylated form was significantly correlated with VEGF production and intratumoral MVD [44]. COX-2 is another important regulator of VEGF in OSCC. COX-2 was demonstrated to regulate VEGF-C levels in OSCC in vitro [45] and in vivo [32,46]. More importantly, COX-2/VEGF$\mathrm{C}$ co-expression is correlated with lymphangiogenesis, lymph node metastasis, TNM stage, lymphatic vessel density and is reported as an independent factor for survival [32]. A summary of the role of VEGF signaling in OSCC is presented in Figure 1.

\subsection{Diagnostics}

About one third of oral cancer patients develop a recurrent tumor after initial treatment. There are several biomarkers that have been proposed to be used for early diagnosis or as prognostic factors in OSCC, being VEGF one of them. Concomitant expression of VEGF and matrix metalloproteinase (MMP)-11, a MMP related with cancer cell survival, has been reported as a predictor for progression from precancerous stage to malignancy [25] and serum VEGF-A levels are reported to be higher in patients with OPMDs than healthy controls, with sensitivity and specificity values of $63 \%$ and $80 \%$ [21]. These data suggest VEGF as a possible biomarker for OPMDs. Nevertheless, there are limited reports that have investigated the potential of VEGF in predicting malignant transformation of OPMDs.

Serum VEGF levels are significantly higher in OSCC than in control patients $[21,27,47]$ and high VEGF levels have been associated with late stage, large tumors and lymph node involvement [27]. According to this, Aggarwal et al. reported sensitivity and specificity values of $65.71 \%$ and $66.67 \%$ for distinguishing OSCC patients from controls [27]. Specifically, serum VEGF-A levels have also been found higher in patients with OSCC than healthy controls. Sensitivity and specificity values were $73 \%$ and $100 \%$, respectively [21]. A follow-up study of 144 patients with OSCC for 115 months showed a direct correlation between VEGF levels and disease-free survival, concluding VEGF expression is an adverse prognosticator for disease-free survival [25]. Similar results have been reported by others $[31,39,46,48,49]$. VEGF expression has also been reported to improve accuracy and efficacy of prognostic prediction of OSCC. A strong VEGF-A or VEGF-C expression contributed to the histopathological diagnosis of vascular invasion, and histopathological feature associated with poor prognosis [22]. Recently, a meta-analysis that evaluated more than 180 biomarkers for oral tongue squamous cell carcinoma (OTSCC) concluded VEGF-A to be a useful prognosticator. Nonetheless, the authors concluded that although VEGF is a very promising biomarker, the utility of VEGF as a prognostic biomarker has to be evaluated in multicentre studies using large cohort of OTSCC samples following REMARK (Reporting Recommendations for Tumor Marker Prognostic Studies) criteria [50].

From all VEGF variants, VEGF-C and VEGF-D seem to be of particular importance for the development of lymph node metastasis. Upregulation of VEGF-C promotes peritumoral lymphangiogenesis and is associated with lymph node metastasis and poor 5-years diseasefree survival [46]. High VEGF-C expression in primary tumors has been associated with a greater probability for the occurrence of micrometastases and isolated tumor cells in pathological staged N0 OSCC [51]. Also, VEGF-C is reported as an independent prognostic factor for lymph node metastases in early tongue cancer [52] and of OSCC survival [32]. In $\mathrm{T} 2$ or $\mathrm{T} 3 \mathrm{cN} 0$ OSCC patients, VEGF-D expression has also been associated with the presence of lymph node metastasis [53]. Because of the aforementioned, the expression of VEGF-C and VEGF-D are proposed as potential biomarkers for detecting and predicting lymph node metastases in OSCC. Nevertheless, other studies have failed in showing independent prognostic utility of VEGF-C for predicting risk of lymph node metastases, 
although they did find a significant association [54,55]. A synthesis of the studies conducted in diagnostics of oral cancer is presented in Table 1.

Table 1. VEGF in oral diagnostics of oral non-communicable diseases.

\begin{tabular}{|c|c|c|c|c|c|}
\hline Author, Year & Study Design & Groups, $n$ & Technique & VEGF Levels & $p$ \\
\hline \multicolumn{6}{|c|}{ Oral Cancer } \\
\hline \multirow[t]{2}{*}{$\begin{array}{l}\text { Sauter et al., } \\
\text { 1999. [14] }\end{array}$} & $\begin{array}{l}\text { Retrospective } \\
\text { without follow-up }\end{array}$ & $\begin{array}{l}\text { FFPE patient tissue } \\
\text { samples from NOM } \\
(n=10), \text { MOD }(n=9), \text { CIS } \\
(n=6), \text { stage I and II } \\
\text { OSCCs }(n=9) \text {, stage III } \\
\text { and IV OSCCs }(n=10) .\end{array}$ & NB, WB, IHC & $\begin{array}{l}\text { VEGF is overexpressed at } \\
\text { both protein and gene } \\
\text { levels in OSCC cells lines } \\
\text { and FFPE tissue samples } \\
\text { compared to normal oral } \\
\text { keratinocyte cell lines and } \\
\text { NOM respectively. }\end{array}$ & $<0.05$ \\
\hline & In vitro & $\begin{array}{l}\text { OSCC and other cell lines } \\
(n=7)\end{array}$ & & & \\
\hline $\begin{array}{l}\text { Nayak et al., } \\
\text { 2012. [21] }\end{array}$ & $\begin{array}{l}\text { Prospective with } \\
\text { follow-up }\end{array}$ & $\begin{array}{l}\text { Tissue biopsies and blood } \\
\text { samples from PMOLs } \\
(n=60) \text {, OSCC }(n=60) \\
\text { and healthy controls } \\
(n=20) .\end{array}$ & IHC, qPCR, ELISA, & $\begin{array}{l}\text { VEGF-A protein and gene } \\
\text { expression were higher in } \\
\text { PMOLs and OSCC } \\
\text { compared to controls and } \\
\text { higher in OSCC with node } \\
\text { involvement than without. }\end{array}$ & $<0.05$ \\
\hline $\begin{array}{l}\text { Seki et al., } \\
\text { 2011. [22] }\end{array}$ & $\begin{array}{l}\text { Retrospective with } \\
\text { follow-up }\end{array}$ & $\begin{array}{l}\text { FFPE patient tissue } \\
\text { samples from well } \\
\text { differentiated OSCCs } \\
(n=72), \text { moderately } \\
\text { differentiated OSCCs } \\
(n=12) \text { and poorly } \\
\text { differentiated OSCCs } \\
(n=6) .\end{array}$ & IHC & $\begin{array}{l}\text { Strong expression of } \\
\text { VEGF-A or VEGF-C were } \\
\text { effective prognostic } \\
\text { predictors of } \\
\text { OSCC survival. }\end{array}$ & $\mathrm{N} / \mathrm{A}$ \\
\hline $\begin{array}{l}\text { Gandolfo et al., } \\
\text { 2011. [20] }\end{array}$ & $\begin{array}{l}\text { Retrospective } \\
\text { without follow-up }\end{array}$ & $\begin{array}{l}\text { FPPE patient tissue } \\
\text { samples from OL with } \\
\text { dysplasia }(n=18), \text { OL } \\
\text { without dysplasia }(n=11) \text {, } \\
\text { OSCC }(n=40) \text { and NOM } \\
(n=20) .\end{array}$ & IHC & $\begin{array}{l}\text { VEGF expression was } \\
\text { higher in OL and OSCC } \\
\text { than NOM and in OL with } \\
\text { dysplasia than OL } \\
\text { without dysplasia. }\end{array}$ & $<0.05$ \\
\hline $\begin{array}{l}\text { López de Cicco } \\
\text { et al., 2004. [24] }\end{array}$ & $\begin{array}{l}\text { Retrospective } \\
\text { without follow-up } \\
\text { In vitro }\end{array}$ & $\begin{array}{l}\text { FFPE patient tissue } \\
\text { samples from ODs } \\
(n=21), \text { OSCCs, }(n=44), \\
\text { NOM }(n=46) \text {. } \\
\text { Three SCC cell lines } \\
\text { (SCC } 9, \text { SCC15, SCC71). }\end{array}$ & IHC & $\begin{array}{l}\text { All NOM samples } \\
\text { presented with low or } \\
\text { mild expression of } \\
\text { VEGF-C, whereas strong } \\
\text { expression was detected in } \\
40 \% \text { of ODs and } 100 \% \\
\text { of OSCCs. }\end{array}$ & $\mathrm{N} / \mathrm{A}$ \\
\hline $\begin{array}{l}\text { Aggarwal et al., } \\
\text { 2014. [27] }\end{array}$ & $\begin{array}{l}\text { Prospective } \\
\text { without follow-up } \\
\text { In vitro }\end{array}$ & $\begin{array}{l}\text { Peripheral venous blood } \\
\text { from patients with OSCC } \\
(n=70) \text { and healthy } \\
\text { subjects }(n=30) \text {. } \\
\text { Fresh OSCC biopsies } \\
(n=17) \text {. } \\
\text { OSCC cell lines }(n=4) .\end{array}$ & qPCR, WB, ELISA & $\begin{array}{l}\text { VEGF expression was } \\
\text { significantly upregulated } \\
\text { in OSCC patients } \\
\text { compared to } \\
\text { healthy controls. } \\
\text { Serum VEGF levels were } \\
\text { also higher in late stage } \\
\text { tumors, large tumors and } \\
\text { tumors with regional } \\
\text { lymph node involvement. } \\
\text { Treatment of OSCC cell } \\
\text { lines with exogenous } \\
\text { VEGF enhanced } \\
\text { cell proliferation. }\end{array}$ & $<0.05$ \\
\hline
\end{tabular}


Table 1. Cont.

\begin{tabular}{|c|c|c|c|c|c|}
\hline Author, Year & Study Design & Groups, $n$ & Technique & VEGF Levels & $p$ \\
\hline $\begin{array}{l}\text { Peterle et al., } \\
\text { 2018. [28] }\end{array}$ & $\begin{array}{l}\text { Retrospective with } \\
\text { follow-up }\end{array}$ & $\begin{array}{l}\text { FFPE patient tissue } \\
\text { samples from OSCCs } \\
(n=52) .\end{array}$ & IHC & $\begin{array}{l}\text { Positive VEGF-A } \\
\text { cytoplasmic expression } \\
\text { was significantly } \\
\text { associated with less } \\
\text { differentiation } \\
\text { tumor grade. }\end{array}$ & 0.035 \\
\hline $\begin{array}{l}\text { Faratzis et al., } \\
\text { 2009. [29] }\end{array}$ & $\begin{array}{l}\text { Retrospective with } \\
\text { follow-up }\end{array}$ & $\begin{array}{l}\text { FFPE patient tissue } \\
\text { samples from TSCC } \\
(n=87) .\end{array}$ & IHC & $\begin{array}{l}\text { VEGF was overexpressed } \\
\text { in } 27.5 \% \text { of all TSCC and } \\
\text { correlated to the stage of } \\
\text { the disease. }\end{array}$ & $<0.05$ \\
\hline
\end{tabular}

No prognostic significance

of VEGF protein

expression to survival

status was found.

\begin{tabular}{|c|c|c|}
\hline $\begin{array}{l}\text { Shang et al., } \\
\text { 2006. [30] }\end{array}$ & $\begin{array}{l}\text { Retrospective } \\
\text { without follow-up }\end{array}$ & $\begin{array}{l}\text { FFPE patient tissue } \\
\text { samples from OSCC } \\
(n=40) \text { and healthy } \\
\text { controls }(n=20) .\end{array}$ \\
\hline
\end{tabular}

Shao et al. 2008. [31]
FFPE patient tissue samples from TSCCs $(n=59)$ and tumor free-oral mucosa $(n=10)$.
IHC, ELISA

VEGF positivity was correlated with regional lymph node involvement and tumor size.

Higher expression of VEGF in TSCC compared to NOM.

VEGF expression was an independent prognostic factor of overall survival was correlated with tumor size, clinical stage, lymph node invasion, recurrence and distant metastasis.

VEGF expression was an independent prognostic factor of overall survival.

VEGF-C expression correlated with gender,

Morita et al., Retrospective with 2014. [32]
FFPE patient tissue samples form TSCC $(n=$ 40).
IHC metastases, lymphatic vessel density.

Significant correlation between COX-2 and

VEGF-C expression which was identified as an $<0.01$ independent prognostic factor of overall survival.

VEGF was expressed in $76 \%$ of OSCCs, in $66 \%$ of PLs and in 25\% of NOM. VEGF expression

FFPE patient tissue samples from OSCCs $(n=$

Arora et al., 2005. [25]
Retrospective with follow-up
220), PL (hyperplasias = 59 , dysplasias $=31$ ) and IHC matched normal oral tissues $(n=81)$. independently correlated with increased intratumoral microvessel density in PLs and OSCC. Increased VEGF expression was the most significant adverse prognosticator in OSCC patients. 
Table 1. Cont.

\begin{tabular}{|c|c|c|c|c|c|}
\hline Author, Year & Study Design & Groups, $n$ & Technique & VEGF Levels & $p$ \\
\hline $\begin{array}{l}\text { Shintani et al., } \\
\text { 2004. [33] }\end{array}$ & $\begin{array}{l}\text { Retrospective } \\
\text { without follow-up }\end{array}$ & $\begin{array}{l}\text { FFPE patient tissue } \\
\text { samples from OSCC } \\
(n=98) \text { and fresh OSCC } \\
\text { specimens }(n=12) .\end{array}$ & IHC, WB, qPCR & $\begin{array}{l}60.2 \% \text { of cases were } \\
\text { positive for VEGF-A, } \\
62.2 \% \text { for VEGF-B, } 67.3 \% \\
\text { for VEGF-C and } 55.1 \% \\
\text { for VEGF-D }\end{array}$ & $\mathrm{N} / \mathrm{A}$ \\
\hline
\end{tabular}

VEGF-A and VEGF-B

positively correlated with

MVD and VEGF-C and

VEGF-D expression were $\quad<0.05$

significantly associated

with lymph

node involvement.

Lee et al. 2018. [38]

Retrospective with follow-up

FFPE patient tissue samples from OSCCs

Shang et al., 2007. [47]

Prospective without follow up
FFPE patient tissue

samples from

hyperkeratosis $(n=8)$ and

IHC

OSCCs $(n=30)$ $(n=31)$ and healthy

controls $(n=10)$.

Peripheral venous blood from OSCCs $(n=31)$ and healthy controls $(n=10)$.
High VEGF expression in upper and lower epithelial layers had significant association in tumor metastasis and recurrence.

Mean VEGF level in

OSCC patients

(567.97 \pm 338.17 pg.ml)

was significantly higher

than in normal controls

(148.80 \pm 64.17 pg.ml) and

were positively correlated

with metastasis and

clinical stage.

VEGF-C levels were

higher in metastatic

tumors than

FFPE patient tissue samples from OSCCs

IHC non-metastatic and patient with high VEGF-C $(n=60)$. shorter DSS tan patient with low expression.

Serum VEGF levels were significantly higher in patients with well

FFPE patient tissue samples from OSCCs $(n=$ 109) and healthy controls $(n=50)$.

Peripheral venous blood from OSCCs $(n=109)$ and healthy controls $(n=50)$.
ELISA, qPCR differentiated recurrencies, large and advanced stage tumors. Patients having lower VEGF serum levels had significantly higher OS compared to patients with higher serum VEGF levels.

Strong VEGF intensity was an independent adverse predictor for OS and DFS.

High expression of VEGF-C in the primary tumor was associated with a greater probability for the occurrence of micrometastasis and isolated tumor cells in the lymph nodes. 
Table 1. Cont.

\begin{tabular}{|c|c|c|c|c|c|}
\hline Author, Year & Study Design & Groups, $n$ & Technique & VEGF Levels & $p$ \\
\hline $\begin{array}{l}\text { Matsui et al., } \\
\text { 2015. [52] }\end{array}$ & $\begin{array}{l}\text { Retrospective with } \\
\text { follow-up }\end{array}$ & $\begin{array}{l}\text { FFPE patient tissue } \\
\text { samples from TSCC } \\
(n=90)\end{array}$ & IHC & $\begin{array}{l}\text { VEGF-C expression was } \\
\text { associated with lymph } \\
\text { node metastases and was } \\
\text { a prognostic factor } \\
\text { for DSS. }\end{array}$ & $<0.05$ \\
\hline \multirow[t]{2}{*}{$\begin{array}{l}\text { Wakisaka et al., } \\
\text { 2015. [53] }\end{array}$} & $\begin{array}{l}\text { Retrospective with } \\
\text { follow-up }\end{array}$ & $\begin{array}{l}\text { FFPE patient tissue } \\
\text { samples from OSCCs } \\
(n=57) .\end{array}$ & IHC & $\begin{array}{l}\text { Tumors with high VEGF-A } \\
\text { and VEGF-D expression } \\
\text { had significantly higher } \\
\text { lymph vessel density than } \\
\text { low expressing tumors. }\end{array}$ & $<0.003$ \\
\hline & & & & $\begin{array}{l}\text { VEGF-D expression was } \\
\text { significantly higher in } \\
\text { tumors with lymph node } \\
\text { metastasis than in } \\
\text { tumor without }\end{array}$ & $<0.001$ \\
\hline
\end{tabular}

Al-Shareef et al., Retrospective with 2016. [55]
FFPE patient tissue samples from TSCCs $(n=80)$.
IHC

VEGF-C and VEGFR-3

were not found

independent predictor

factors for lymph node metastasis of TSCCs.

VEGF-C expression was associated with growth pattern and deep of invasion and VEGFR-3

Naruse et al., Retrospective with FFPE patient tissue 2015. [54]
IHC samples from TSCCs $(n=65)$. expression was associated with growth pattern, pattern of invasion, deep of invasion and regional recurrences.

\section{VEGF-C/VEGFR-3}

expression was associated with regional recurrence, but was not identified as an independent factor for recurrence.
Inflammatory (periodontitis, periimplantitis, apical periodontitis)

$<0.05$

$>0.05$

VEGF was detected in junctional, sulcular and gingival epithelium, neutrophils, macrophages and vascular endothelial cells. Some fibroblast was positive.

No difference between saliva from patients with periodontitis $(n=32)$ and

IHC, ELISA VEGF levels in GCF between both groups. Higher levels of VEGF in saliva of patients with periodontitis in relation to controls. 
Table 1. Cont.

\begin{tabular}{ccccc}
\hline Author, Year & Study Design & Groups, $n$ & Technique & VEGF Levels \\
\hline Inflammatory (periodontitis, periimplantitis, apical periodontitis) & & $p$
\end{tabular}

Inflammatory (periodontitis, periimplantitis, apical periodontitis)

$\begin{array}{lll} & & \mathrm{GCF} \text { and saliva from } \\ & \mathrm{G}-\operatorname{AgP}(n=20), \mathrm{CP} \\ & (n=20), \text { gingivitis } \\ \text { Afacan et al., } \quad \text { Cross-sectional } \quad \text { individuals }(n=26) \text { and } \\ \text { 2019. } \quad \text { healthy periodontal } \\ \text { patients }(n=21) .\end{array}$

GCF and saliva from$$
(n=20) \text {, gingivitis }
$$$$
\text { healthy periodontal }
$$$$
\text { patients }(n=21) \text {. }
$$

Higher total amounts of

VEGF in GCF from G-AgP

and $\mathrm{CP}$ groups than

gingivitis and healthy groups, without difference

between $\mathrm{G}-\mathrm{AgP}$ and $\mathrm{CP}$,

whereas in saliva VEGF

presented higher

concentrations in

gingivitis than healthy, $\mathrm{CP}$

and AgP groups.

GCF and plasma from patients with generalized

Sosnin et al., 2019. [58]

Cross-sectional periodontitis $(n=42)$ and control healthy group $(n=36)$.

Saliva and serum from patients with periodontitis (20 smokers and 20

Şaştım et al., Cross-sectional 2020. [59] nonsmokers) and periodontally healthy controls (20 smokers and 18 nonsmokers).
ELISA

No differences in the

concentration of saliva and serum VEGF.

$<0.05$

Higher concentrations of

VEGF in saliva and serum in patients with periodontitis than periodontally healthy controls.

No difference in the concentrations of VEGF in saliva and serum between smokers and no smokers.

Higher concentrations of VEGF in from GAgP patients than healthy controls. Significant

GCF from GAgP patients Multiplex bead controls $(n=22)$. immunoassay reduction of VEGF total amount after therapy in GAgP patients.
Romano et al., Cross-sectional 2017. [60]

No difference levels of

VEGF among

GCF from patients with

A. Zekeridou et al., 2017. [61]

Cross-sectional chronic periodontitis $(n=24)$ and healthy controls $(n=20)$.
Bio-Plex suspension array system periodontitis site and healthy sites from periodontitis individuals and healthy sites from healthy control.

GCF from patients with generalized chronic Tayman et al., 2019. [62]

Cross-sectional periodontitis $(n=21)$, generalized aggressive periodontitis $(n=20)$ and healthy $(n=20)$.

PICF from patients with peri-implantitis affected Wang et al., 2016. [63]
Cross-sectional implant $(n=34)$ and healthy implant control $(n=34)$.
Highest total

concentration of VEGF,

followed by chronic periodontitis groups and lowest concentration in healthy controls.

Human

Quantibody arrays

Higher levels of VEGF in the peri-implantitis patients in relation to healthy implant control. 
Table 1. Cont

\begin{tabular}{|c|c|c|c|c|c|}
\hline Author, Year & Study Design & Groups, $n$ & Technique & VEGF Levels & $p$ \\
\hline \multicolumn{6}{|c|}{ Inflammatory (periodontitis, periimplantitis, apical periodontitis) } \\
\hline $\begin{array}{l}\text { Graziani et al., } \\
\text { 2006. [64] }\end{array}$ & Cross-sectional & $\mathrm{RC}(n=24)$ & $\mathrm{IHC}$ & $\begin{array}{l}\text { VEGF was detected in } \\
\text { epithelial and connective } \\
\text { tissues of RCs. Stromal } \\
\text { cells showed higher levels } \\
\text { of VEGF expression when } \\
\text { compared with epithelial } \\
\text { cells. }\end{array}$ & $>0.05$ \\
\hline $\begin{array}{l}\text { Fonseca-Silva } \\
\text { et al., 2012. [65] }\end{array}$ & Cross-sectional & $\mathrm{RC}(n=40), \mathrm{PG}(n=28)$ & $\mathrm{IHC}$ & $\begin{array}{l}\text { VEGF expression were } \\
\text { similar in RC and PG. }\end{array}$ & $>0.05$ \\
\hline $\begin{array}{l}\text { Virtej et al., } \\
\text { 2013. [66] }\end{array}$ & Cross-sectional & $\begin{array}{l}\text { ALEOs }(n=14) \text { after } \\
\text { endodontic surgery in } \\
\text { patients diagnosed with } \\
\text { CAP and PDL control } \\
\text { samples }(n=4) \text {. }\end{array}$ & qPCR & $\begin{array}{l}\text { Higher gene expression of } \\
\text { VEGF-A and VEGFR-3 in } \\
\text { ALEOS in comparison } \\
\text { with PDL group. }\end{array}$ & $>0.05$ \\
\hline $\begin{array}{l}\text { Fernandez et al., } \\
\text { 2020. [67] }\end{array}$ & Cross-sectional & $\begin{array}{l}\text { Symtomatic } \operatorname{AP}(n=17), \\
\text { asymptomatic } \operatorname{AP}(n=17) .\end{array}$ & qPCR & $\begin{array}{l}\text { No difference in levels of } \\
\text { VEGF-A mRNA. }\end{array}$ & $>0.05$ \\
\hline
\end{tabular}

NOM: Normal oral mucosa, MOD: moderate oral displasia, CIS: carcinoma in situ, OSCC: Oral squamous cell carcinoma, HNSCC: head and neck squamous cel carcinoma, SCC: squamous cell carcinoma, OD: oral dysplasia, OL: oral leukoplakia, TSCC: tongue squamous cell carcinoma, NB: northern blot, WB: western blot, IHC: Immunohistochemistry, PMOL: potentially malignant oral lesion, PL: precancerous lesion, MVD: microvessel density, qPCR: quantitative PCR, N/A: not available., OS: overall survival, DFS: disease-free survival, DSS: disease-specific survival, GCF: gingival crevicular fluid, G-AgP: Generalized aggressive periodontitis, CP: chronic periodontitis, PICF: peri-implant crevicular fluid, PG: Periapical granulomas, RC: Radicular cysts, RRC: Residual radicular cysts, AP: Apical periodontitis, ALEO: Apical lesion of endodontic origin, CAP: apical periodontitis, PDL: periodontal ligament.

\subsection{Therapy and Projections}

In comparison to normal tissues, tumor vasculature presents atypical morphological features, such as dilated, tortuous and disorganized blood vessels. This leads to excessive permeability, poor perfusion, hypoxia, decreased immune cell infiltration and predisposition to metastatic dissemination [68], features that can impact negatively on clinical outcome. The development of an abnormal tumor vasculature is associated with an increase in different growth factors, of which VEGF is a key player [69]. VEGF mRNA is overexpressed in the majority of human tumors and correlates with invasiveness, vascular density, metastasis, recurrences, and prognosis. Thus, different strategies to inhibit the VEGF/VEGFR signaling pathway have been developed [1]. Angiogenesis inhibition by targeting VEGF has shown to be an effective treatment of OSCC in in vivo animal models [70-72] and in vitro [73]. There are several anti-VEGF family agents, which include bevacizumab, sorafenib, vandetanib, among others [74], that have been tested for OSCC treatment.

Bevacizumab, a humanized monoclonal antibody against VEGF-A, is one of the most commonly used drugs in oncology. It has FDA approval for the treatment of colorectal cancer, renal cell carcinoma, non-small-cell lung carcinoma, glioblastoma multiforme, ovarian cancer and cervical cancer [75]. Different phase II clinical trials have reported the utility of bevacizumab for treatment of squamous cell carcinoma of the head and neck (SSCHN) - which includes OSCC — as part of combinatorial treatments. This includes the use of bevacizumab in combination with: erlotinib [76], pemetrexed [77], cetuximab, cisplatin and concurrent intensity modulated radiation therapy [78]. A recent phase III clinical trial which evaluated the addition of bevacizumab to platinum-based chemotherapy in recurrent or metastatic SCCHN, showed that the addition of bevacizumab did not improve overall survival but did improve response rate and progression-free survival. Nevertheless, there was a significant increase in toxicity, including bleeding events and treatment related deaths [79]. 
Sorafenib and vandetanib are multi-kinases inhibitors that among their different targets, they also inhibit VEGFR. Sorafenib has FDA approval for the treatment of hepatocellular carcinoma [74] and in vitro studies have suggested promising effects of sorafenib as treatment agent for SCCHN [80,81]. Nonetheless, phase II clinical trials have shown modest $[82,83]$ or none [84] anti-tumor activity of sorafenib for the treatment of recurrent or metastatic SCCHN. Vandetanib has also shown promising results in animal models for OSCC treatment. In a mouse 4-NQO model of oral carcinogenesis, vandetanib decreased the occurrence of tumors and dysplasia by reducing angiogenesis and proliferation, probably by inhibiting VEGFR and epidermal growth factor receptor (EGFR) [85]. Nevertheless, a phase II clinical trial that evaluated vandetanib in combination with docetaxel for the treatment of recurrent or metastatic SCCHNC showed limited utility of the proposed treatment regimen [86]. A synthesis of the studies conducted in therapeutics of oral cancer is presented in Table 2 .

Table 2. VEGF pathway therapeutics in oral non-communicable diseases.

\begin{tabular}{|c|c|c|c|c|c|}
\hline Author, Year & $\begin{array}{c}\text { Study Design } \\
\text { (RCT/Preclinical-Animal } \\
\text { Model) }\end{array}$ & Intervention & Function & Outcome & $p$ \\
\hline \multicolumn{6}{|c|}{ Cancer } \\
\hline $\begin{array}{l}\text { Cohen et al., } \\
\text { 2009. [76] }\end{array}$ & $\begin{array}{l}\text { Phase I and phase II trials in } \\
\text { patients with recurrent or } \\
\text { metastatic HNSCC }\end{array}$ & $\begin{array}{l}\text { Bevacizumab }(15 \mathrm{mg} / \mathrm{kg} \\
\text { every } 3 \text { weeks })+ \text { erlotinib } \\
(150 \mathrm{mg} \text { /day })\end{array}$ & $\begin{array}{l}\text { Bvacizumab: anti-VEGF } \\
\text { monoclonal antibody } \\
\text { Erlotinib: EGFR inhibitor. }\end{array}$ & $\begin{array}{l}\text { Response rate was of } 15 \% \\
\text { with } 4 \text { complete } \\
\text { responses (associated } \\
\text { with expression of } \\
\text { putative targets in } \\
\text { pre-treatment } \\
\text { tumor tissue). }\end{array}$ & $\mathrm{N} / \mathrm{A}$ \\
\hline $\begin{array}{l}\text { Argiris et al., } \\
\text { 2011. [77] }\end{array}$ & $\begin{array}{l}\text { Phase II trial in patients with } \\
\text { recurrent or } \\
\text { metastatic HNSCC }\end{array}$ & $\begin{array}{l}\text { Bevacizumab }(15 \mathrm{mg} / \mathrm{kg} \\
\text { every } 21 \text { days })+ \\
\text { Pemetrexed }\left(500 \mathrm{mg} / \mathrm{m}^{2}\right) \\
\text { every } 21 \text { days. }\end{array}$ & $\begin{array}{l}\text { Bvacizumab: anti-VEGF } \\
\text { monoclonal antibody } \\
\text { Pemetrexed: } \\
\text { multitargeted antifolate } \\
\text { agent. }\end{array}$ & $\begin{array}{l}\text { Overall response rate was } \\
\text { of } 30 \%(90 \% \text { CI, } 17-42 \%) \text {, } \\
\text { disease control rate of } \\
86 \%(90 \% \text { CI, } 77-96 \%) \\
\text { and there were } 2 \\
\text { complete responses }(5 \%) \text {. }\end{array}$ & $\mathrm{N} / \mathrm{A}$ \\
\hline $\begin{array}{l}\text { Fury et al., } \\
\text { 2016. [78] }\end{array}$ & $\begin{array}{l}\text { Phase II trial in patients with } \\
\text { stage III/IVB HNSCC }\end{array}$ & $\begin{array}{l}\text { Bevacizumab }(15 \mathrm{mg} / \mathrm{kg}) \\
\text { on day } 1 \text { and } 22+ \\
\text { Cetuximab }\left(400 \mathrm{mg} / \mathrm{m}^{2}\right. \\
\text { on day minus } 7 \text { followed } \\
\text { by weekly dosing of } \\
\left.250 \mathrm{mg} / \mathrm{m}^{2}\right)+ \text { Cisplatin } \\
\left.\text { (two cycles of } 50 \mathrm{mg} / \mathrm{m}^{2}\right) \\
\text { with concurrent IMRT. }\end{array}$ & $\begin{array}{l}\text { Bvacizumab: anti-VEGF } \\
\text { monoclonal antibody } \\
\text { Cetuximab: anti-EGFR } \\
\text { chimeric monoclonal } \\
\text { antibody. }\end{array}$ & $\begin{array}{l}\text { The 2-year progression } \\
\text { free survival was of } 88.5 \% \\
(95 \% \text { CI, } 68.1-96.1) \text { and } \\
\text { the 2-year overall } \\
\text { survival of } 92.8 \%(95 \% \text { CI, } \\
74.2-98.1 \%) \text {. }\end{array}$ & $\mathrm{N} / \mathrm{A}$ \\
\hline $\begin{array}{l}\text { Argiris et al., } \\
\text { 2019. [79] }\end{array}$ & $\begin{array}{l}\text { Phase III RCT in patients with } \\
\text { recurrent or } \\
\text { metastatic HNSCC }\end{array}$ & $\begin{array}{l}\text { Platinum based } \\
\text { chemotherapy doublet } \\
\text { with or without } \\
\text { Bevacizumab ( } 15 \mathrm{mg} / \mathrm{kg} \\
\text { every } 3 \text { weeks). }\end{array}$ & $\begin{array}{l}\text { Cetuximab: anti-EGFR } \\
\text { chimeric monoclonal } \\
\text { antibody. }\end{array}$ & $\begin{array}{l}\text { Median overall survival } \\
\text { was } 12.6 \text { months for the } \\
\text { group of chemotherapy }+ \\
\text { bevacizumab (BC) and of } \\
11 \text { months for } \\
\text { chemotherapy alone. } \\
\text { Median progression-free } \\
\text { survival with BC was } 6.0 \\
\text { months v } 4.3 \text { months } \\
\text { with chemotherapy. } \\
\text { Overall response rates } \\
\text { were of } 35.5 \% \text { with BC } \\
\text { and } 24.5 \% \\
\text { with chemotherapy. }\end{array}$ & 0.0014 \\
\hline
\end{tabular}


Table 2. Cont.

\begin{tabular}{|c|c|c|c|c|c|}
\hline Author, Year & $\begin{array}{c}\text { Study Design } \\
\text { (RCT/Preclinical-Animal } \\
\text { Model) }\end{array}$ & Intervention & Function & Outcome & $p$ \\
\hline $\begin{array}{l}\text { Lalami et al., } \\
\text { 2016. [83] }\end{array}$ & $\begin{array}{l}\text { Phase II trial in recurrent or } \\
\text { metastatic HNSCC }\end{array}$ & $\begin{array}{l}\text { Sorafenib ( } 1 \text { cycle: } 400 \mathrm{mg} \\
\text { twice daily for } 28 \text { days). }\end{array}$ & $\begin{array}{l}\text { Sorafenib: Multitarget } \\
\text { small molecule inhibitor } \\
\text { of wild-type and mutant } \\
\text { B-Raf and c-Raf kinases, } \\
\text { and tyrosine kinase } \\
\text { domain of VEGFR-2,3 } \\
\text { among others. }\end{array}$ & $\begin{array}{l}\text { Only } 1 \text { patient had partial } \\
\text { response }(5 \%), 12 \text { patients } \\
(55 \%) \text { had stable disease } \\
\text { and } 9 \text { patients }(40 \%) \text { had } \\
\text { progressive disease. Early } \\
\text { metabolic response rate } \\
\text { was } 38 \% \text {. }\end{array}$ & $\mathrm{N} / \mathrm{A}$ \\
\hline $\begin{array}{l}\text { Gilbert et al., } \\
\text { 2015. [84] }\end{array}$ & $\begin{array}{l}\text { Randomized phase II trial in } \\
\text { recurrent or } \\
\text { metastatic HNSCC }\end{array}$ & $\begin{array}{l}\text { Cetuximab }\left(400 \mathrm{mg} / \mathrm{m}^{2}\right) \\
\text { on day } 1 \text { followed by } \\
250 \mathrm{mg} / \mathrm{m}^{2} \text { weekly) with } \\
\text { or without Sorafenib } \\
\text { ( } 400 \mathrm{mg} \text { twice daily). }\end{array}$ & $\begin{array}{l}\text { Cetuximab: anti-EGFR } \\
\text { chimeric monoclonal } \\
\text { antibody } \\
\text { Sorafenib: Multitarget } \\
\text { small molecule inhibitor } \\
\text { of wild-type and mutant } \\
\text { B-Raf and c-Raf kinases, } \\
\text { and tyrosine kinase } \\
\text { domain of VEGFR-2,3 } \\
\text { among others. }\end{array}$ & $\begin{array}{l}\text { Response rate was of } 8 \% \\
\text { and clinical benefit of } 12 \% \\
\text { for both groups. } \\
\text { Median overall survival } \\
\text { was } 9 \text { months in the } \\
\text { cetuximab only group } \\
\text { and } 5.7 \text { months in the } \\
\text { combined group. }\end{array}$ & 0.41 \\
\hline $\begin{array}{l}\text { Zhou et al., } \\
\text { 2010. [85] }\end{array}$ & $\begin{array}{l}\text { Mouse 4-NQO model of oral } \\
\text { carcinogenesis }\end{array}$ & $\begin{array}{l}\text { Vandetanib } \\
(25 \mathrm{mg} / \mathrm{Kg} / \text { day for } \\
24 \text { weeks) or nothing. }\end{array}$ & $\begin{array}{l}\text { Vandetanib: Tyrosine } \\
\text { kinase inhibitor with } \\
\text { direct activity against } \\
\text { multiple. Signal } \\
\text { transduction pathways } \\
\text { including VEGF-R2 } \\
\text { and EGFR. }\end{array}$ & $\begin{array}{l}\text { The use on Vandetanib } \\
\text { reduced the occurrence of } \\
\text { OSCC from } 71 \% \text { to } 12 \% \\
\text { and of OD from } 96 \% \\
\text { to } 28 \% \text {. }\end{array}$ & $<0.001$ \\
\hline $\begin{array}{l}\text { Limaye et al., } \\
\text { 2013. [86] }\end{array}$ & $\begin{array}{l}\text { Randomized phase II trial in } \\
\text { recurrent or } \\
\text { metastatic HNSCC }\end{array}$ & $\begin{array}{l}\text { Docetaxel }\left(75 \mathrm{mg} / \mathrm{m}^{2}\right. \\
\text { every } 21 \text { days) with or } \\
\text { without vandetanib ( } 100 \\
\mathrm{mg} \text {, once a day). }\end{array}$ & $\begin{array}{l}\text { Docetaxel: antimitotic } \\
\text { chemotherapeutic } \\
\text { Vandetanib: Tyrosine } \\
\text { kinase inhibitor with } \\
\text { direct activity against } \\
\text { multiple signal } \\
\text { transduction pathways } \\
\text { including VEGF-R2 } \\
\text { and EGFR. }\end{array}$ & $\begin{array}{l}\text { Partial response was } \\
\text { observed in } 1 \text { patient ( } n= \\
14 \text { ) of the docetaxel only } \\
\text { group and } 2 \text { patients ( } n= \\
15 \text { ) of the combined } \\
\text { group. } \\
\text { Response rate and } \\
\text { median overall survival } \\
\text { were of } 7 \% \text { ( } 95 \% \text { CI, } \\
0.2-33.8 \% \text { ) and } 26.8(95 \% \\
\text { CI, } 17.7-100.7+) \text { weeks in } \\
\text { the single group and } 13 \% \\
\text { (95\% CI, } 1.6-40.4 \%) \text { and } \\
24.1(95 \% \text { CI, } 16.4-171.1+) \\
\text { weeks in the combined } \\
\text { group. }\end{array}$ & $\mathrm{N} / \mathrm{A}$ \\
\hline \multicolumn{6}{|c|}{ Inflammatory (periodontitis, periimplantitis, apical periodontitis) } \\
\hline $\begin{array}{l}\text { Messer et al., } \\
\text { 2020. [87] }\end{array}$ & Animal model & $\begin{array}{l}\text { Anti-VEGF bvacizumab } \\
\text { ( } 5 \mathrm{mg} \text { B20-4.1.1/ } \mathrm{kg} \text { body } \\
\text { weight, twice weekly. }\end{array}$ & $\begin{array}{l}\text { Bvacizumab: anti-VEGF } \\
\text { monoclonal antibody. }\end{array}$ & $\begin{array}{l}\text { Rats developed mild to } \\
\text { severe mandibular } \\
\text { periodontitis. }\end{array}$ & $\mathrm{N} / \mathrm{A}$ \\
\hline $\begin{array}{l}\text { Al Subaie et al., } \\
\text { 2015. [88] }\end{array}$ & Animal model & $\begin{array}{l}\text { Anti-VEGF, } 4 \text { ug diluted } \\
\text { in } 1.5 \mathrm{~mL} \text { of saline, three } \\
\text { times per week. }\end{array}$ & $\begin{array}{l}\text { Anti-vascular endothelial } \\
\text { growth factor } \\
\text { neutralizing antibody: } \\
\text { the blockage of VEGF-A. }\end{array}$ & $\begin{array}{l}\text { Larger volume of the } \\
\text { bone defects in the } \\
\text { anti-VEGF rats in relation } \\
\text { to controls. }\end{array}$ & 0.026 \\
\hline
\end{tabular}

HNSCC: head and neck squamous cell carcinoma, VEGF: vascular endothelial growth factor, EGFR: epithelial growth factor receptor, N/A: not available, CI: confidence interval, IMRT: intensity modulated radiation therapy, 4-NQO: 4-nitroquinolile 1-oxide, OSCC: oral squamous cell carcinoma, OD: oral dysplasia.

\section{Inflammatory Diseases Affecting Periodontal Tissues}

Inflammatory conditions affecting periodontal tissues include periodontitis, periimplantitis and apical periodontitis (AP). They share common etiopathogenic mechanisms that lead to the development of inflammatory periodontal lesions in response to oral bacterial consortia with alveolar bone loss as their main hallmark. While periodontal lesions in periodontitis and peri-implantitis comprise the marginal periodontal supporting tissues, the target of apical periodontitis are the peri-radicular periodontal tissues [89-91]. In this context, the striking role of VEGF in angiogenesis might relate to the formation of 
granulation tissue in destructive periodontal lesions [92], nutrient level restoration and immune cell migration [71]. Moreover, an intimate connection between immune cells and the endothelium occurs during inflammation. Immune cells induce the activation of the inflammasome and the NFKB signaling pathway, which in turn activates the VEGF/VEGFR axis in endothelial cells, inducing vasodilatation (edema) and increasing vascular permeability [21,22]. The activation of the endothelium permits leukocytes to transmigrate from the blood to the site of injury [40]. VEGF is the main soluble factor that modifies the endothelial barrier [41-43] and secreted by neutrophils, platelets, macrophages, activated-T cells, dendritic cells, pericytes, and the endothelial cells themselves [44].

\subsection{Periodontitis and Peri-Implantitis}

Periodontitis is a chronic immune-inflammatory disease that develops from the combination of a dysbiotic polymicrobial community and a susceptible host $[93,94]$ resulting in the loss of periodontal supporting tissues. Its features include gingival inflammation and bleeding, pocket formation (pathologically deepened gingival sulcus), attachment loss and alveolar bone resorption $[89,95]$. Periodontitis is highly prevalent in adults and a primary cause of tooth loss. In addition, emerging evidence associates periodontitis with higher morbidity and mortality of systemic non-communicable diseases, such as cardiovascular diseases [94,96]. On the other hand, peri-implantitis is the inflammation of the adjacent soft and hard tissues surrounding a dental implant. In a similar manner to periodontitis, it is clinically characterized by bleeding, increased pocket formation and suppuration, resulting from polymicrobial anaerobic infection that leads to rapid bone resorption and implant failure $[91,97,98]$.

Periodontitis is characterized by angiogenic changes within the periodontal tissues. These include the neoformation of loop-like blood vessels in association with increased vascular permeability. These changes appear to facilitate the arrival of proinflammatory cells, chemical mediators, and growth factors to the periodontal tissues, which ultimately exacerbate periodontal inflammation and destruction [99-101]. VEGF has been highly expressed in gingival tissue samples from periodontitis patients in relation to gingivitis and healthy gingiva $[102,103]$. VEGF has been detected in the depths of the gingival stroma, particularly within smooth muscle cells of vascular structures, macrophages, mast cells, fibroblast-like cells, neutrophils and plasma cells in addition to endothelial cells $[93,103]$. Up to now, few reports have explored an association between VEGF and SNPs in periodontitis. Specifically, the position-936 has been previously associated with periodontitis [104] whereas 2578 C/A, rs699947 polymorphism remains controversial [105]. In the same line, higher VEGF immunohistochemical expression in the mucosa of peri-implantitis patients was reported in comparison to peri-implant healthy mucosa and peri-implant mucositis, in which no hard tissue loss occurs [106]. In contrast, lower expression of VEGF was observed in soft tissues surrounding failing implants than in normal gingiva [107]. These findings suggest that VEGF may play a role in the pathogenesis and/or progression of periodontitis and peri-implantitis.

Also, overexpression of VEGF-C in transgenic keratin 14 (K14)-VEGFC mice has been reported, which was followed by lymphatic vessel hyperplasia in normal gingival tissues, without changes in the blood vessels. In normal conditions, K14-VEGFC mice showed increased recruitment of immune cells and higher alveolar bone in relation to their wildtype littermates. Nevertheless, after induction of periodontitis, K14-VEGFC and wild-type mice showed no significant differences in bone resorption, angiogenesis, recruitment of immune cells, levels of MMPs, proinflammatory cytokines, and bone-related proteins in gingival tissue samples. Therefore, VEGF-C may participate in lymphatic endothelial cell proliferation with no impact in periodontitis development [108]. VEGF-C, -D, and VEGFR-3 have been detected in endothelial cells and keratinocytes in healthy gingiva. VEGF-C and VEGFR-3 were also detected in fibroblast-like cells and lymphatic vessels, respectively. After challenging with lipopolysaccharide (LPS) or IL-6/sIL-6R complex, gingival fibroblasts increased the secretion and gene expression of VEGF-A and -C compared 
to non-induced controls, while VEGF-D was not detected. Altogether, VEGF-A and -C contributes to both the angiogenesis and lymphangiogenesis processes in the pathogenesis of periodontitis [109].

During periodontal inflammation, tissue damage increases oxygen consumption resulting in a hypoxic microenvironment. In this context, in vitro studies support the involvement of the HIF- $1 \alpha$. In line with this, a hypoxic microenvironment combined with the presence of lipopolysaccharide (LPS) from $P$. gingivalis -a keystone periodontopathogen in periodontitis- induce the translocation of HIF- $1 \alpha$ into the nucleus, which then dimerizes with HIF-1 $\beta$, up-regulating the transcription of VEGF in human periodontal ligament and gingival fibroblast cells [110-112]. In addition, IL-1 upregulated the transcriptional levels of HIF-1 $\alpha$ in human gingival fibroblasts [113], which is the most abundant cell type in gingival connective tissues [114]. Accordingly, higher HIF-1 $\alpha$ and VEGF concentrations have been found in gingival biopsies from periodontal pockets compared to gingivitis and healthy gingiva sites [115]. Likewise, other studies have shown that VEGF concentrations correlate positively with saliva and GCF HIF-1 $\alpha$ concentrations in periodontal patients [57].

It is known that redox balance can modify periodontal tissue responses $[113,116]$. Recently, our research group showed that hydrogen peroxide treatment increased the levels of gelatinolytic MMPs activity in human periodontal ligament fibroblasts, through the activation of the NF- $\mathrm{BB}$ pathway and intracellular calcium signaling [117]. Hydrogen peroxide also upregulated VEGF and cytokine levels (including IL-6 and CXCL12), while MMP inhibition reduced the bioavailability of VEGF and CXCL12, also decreasing fibroblast migration and wound healing [117]. These results might be explained by atypical activation of the NF- $\mathrm{kB}$ pathway in response to the phosphorylation of $\mathrm{I} \kappa \mathrm{B} \alpha$ and p65 caused by hydrogen peroxide $[118,119]$. The redox-MMP interaction highlights the complexity of the networks involving VEGF during periodontal inflammation. Arguably, VEGF bioavailability might result from proteolytic cleavage and release from its cryptic form from the extracellular matrix [117].

Evidence has shown the link between periodontitis and systemic diseases, including diabetes, cardiovascular disease, rheumatoid arthritis, and adverse pregnancy outcomes [94,120-123]. VEGF expression has been analyzed in both, periodontal tissue samples and oral gingival crevicular fluid (GCF) of diabetic patients to explore the plausibility of this association [124-128]. A recent review described higher VEGF expression and concentrations in periodontal tissue and GCF samples, respectively of diabetic patients with periodontitis compared to nondiabetic controls [128]. These outcomes suggest that diabetes might influence the expression of VEGF in periodontal tissues. It is theorized that this may be a consequence of insulin resistance and endothelial dysfunction, both frequently observed in patients with diabetes. In contrast, similar studies exploring cardiovascular disease show that the concentrations of VEGF in the serum and GCF of patients are unrelated to periodontitis $[129,130]$.

\subsection{Apical Periodontitis}

Apical periodontitis (AP) is an immune-inflammatory pathology that involves the destruction of peri-radicular periodontal tissues as consequence of the persistent microbial infection of the root canal system and the host immune responses against it [131]. As periodontitis, AP is also a determinant cause of tooth loss and has been associated with low-grade systemic inflammation and the development of several non-communicable diseases, especially cardiovascular diseases [132]. The hallmark of this pathology is the formation of an osteolytic apical lesion of endodontic origin [56,90]. From a histopathological point of view, ALEOs will correspond either to periapical granulomas (PGs) or radicular cysts (RCs). The former consists of granulation tissue, which is highly rich in neo forming blood vessels [133].

Persistent root canal infection causes the release of pathogenic bacteria and/or their bioproducts into the periradicular tissues where periodontal ligament cells regulate the chemotaxis of infiltrating leukocytes [134], activating humoral and cellular responses. As a 
reaction to harmful exogenous elements, inflammation presents typical signs that include vasodilatation, uprising cellular metabolism, cellular influx, alteration of blood flow and extravasation of fluids [135].

VEGF has been detected in human PGs and RCs $[65,136]$ at the connective tissue of both PGs and RCs and the epithelial lining of RCs $[64,136]$. This pattern of expression can be linked to wound healing, which coexists with inflammatory destruction during AP development. Furthermore, VEGF is also expressed in residual RC [136], defined as a RC which was not removed after the extraction of the causal infected tooth [137]. In fact, VEGF expression in residual RCs is lower compared to RC and PG [136], presumably because of the lack of remnant bacterial toxin stimulation. VEGF expression has also been associated with high MVD areas of both PGs and RCs [64], which reinforces its participation in neo vessel formation in AP. In ALEOs, VEGF could also contribute to the survival and maintenance of the capillary networks, as in vitro studies have determined that this growth factor prevents apoptosis of microvascular endothelial cells [138-140].

The activity and progression in AP are represented in two clinical stages of the disease; symptomatic AP and asymptomatic AP. The immune response is exacerbated in symptomatic AP, due to a loss of balance between the immune response and the bacterial infection of the root canal system [141]. Our study group has previously demonstrated that the expression of toll-like receptors (TLR)-2 and -4, which are involved in the recognition of damage and pathogen molecular patterns, were positively correlated with VEGF-A in human ALEOs. In the same study, mRNA levels of VEGF-A were detected in both, asymptomatic and symptomatic AP [67]. The detection of VEGF-A in both clinical entities is related to its role in endothelial cell proliferation associated with chronic inflammation, apparently without participation in the clinical exacerbation of the disease. Instead, the symptoms might be mediated by other cytokines and angiogenic factors, like IL-6, TNF- $\alpha$ and $\mathrm{CDH} 5$, which were significantly higher in symptomatic compared to asymptomatic AP [67].

Besides the above-mentioned in vitro study, in which VEGF soluble levels were significantly augmented by peroxide exposure and reduced by MMPs inhibition in hydrogen peroxide-stimulated human periodontal ligament fibroblasts [117], the relationship between MMP-9 and VEGF is further observed in human ALEOs. A strong expression of MMP-9 in human ALEOs has been previously associated with a significantly higher number of immunopositive cells for VEGF [142]. It has also been suggested that some inflammatory cells might be responsible for the synthesis and release of VEGF-A in early phases of AP [143], upregulating their multiple functions in inflamed tissues.

The signaling pathways of VEGF in human ALEOs have also been studied [66]. VEGFA-dependent pathologic angiogenic signaling pathways appear through the activation of protein kinase C- $\gamma($ PKC- $\gamma)$ via Scr-dependent phospholipase D1 (PLD1) [144]. The activation of PKC- $\gamma$ induces the proliferation and migration of microvascular endothelial cells and promotes the tube formation [144]. The PKC gene is upregulated in human ALEOs in comparison to healthy periodontal ligament (PDL), which indicates a higher endothelial activity among periapical inflammation [66]. In this study, a higher expression of phospholipase A (PLA2G6) and phosphoinositide 3-kinase (PIK3) genes were also demonstrated [66]. These genes are involved in pathologic angiogenesis and endothelial migration, respectively [145-147]. Other genes involved in endothelial cell interactions and activity are down regulated in human ALEOs. SHC adaptor protein 2 (SHC2), which is commonly expressed in endothelial cells and participates in VEGFR-2 activation, was down regulated in AP in comparison with healthy PDL samples [66]. Also, VEGFR-2 and RAC1 expression, involved in pathologic and physiologic angiogenesis [148], were lower in the ALEOs group [66]. Overall, in inflamed periapical tissues there is an alteration in the expression of several genes which may contribute to changes in endothelial cell activity and/or interactions.

During inflammation lymphocytes, macrophages [149] and dendritic cells [150] exhibit the expression of VEGF-A, $-\mathrm{C},-\mathrm{D}$ and their receptors. This pattern is reproduced in immune 
cells and blood vessel endothelium in rat and human ALEOs $[66,151]$. The detection of VEGF and VEGFR in these cellular components of the immune system and their localization suggests that VEGFs may participate in the pathogenesis of ALEOs [66]. In vitro studies have demonstrated that VEGF promotes chemotaxis of immune cells [152,153], contributing to the extravasation of them to locally inflamed tissues. According to the localization of the receptors of VEGF in ALEOs it is also possible that immune cells functions take place through autocrine regulation of VEGFR-2 and -3 [66].

The expression of the VEGF family of cytokines and their receptors in osteoblasts and osteoclasts have been described, linking vascular growth and bone turnover [154,155]. Up to now their presence has been reported in experimentally-induced ALEOs in rats, particularly in osteoclasts where VEGFR-2 and -3 were also detected [151]. The signaling mechanisms of VEGF-A through VEGFR-1 are regarded to promote osteoclast differentiation [156]; whereas VEGFR-2 activation is associated with osteoclastic bone resorption [157]. The positive localization of VEGFR-2 in AP might explain one of the pathways responsible for loss of peri-radicular bone.

A summary of the role of VEGF signaling in inflammatory periodontal diseases is presented in Figure 2.

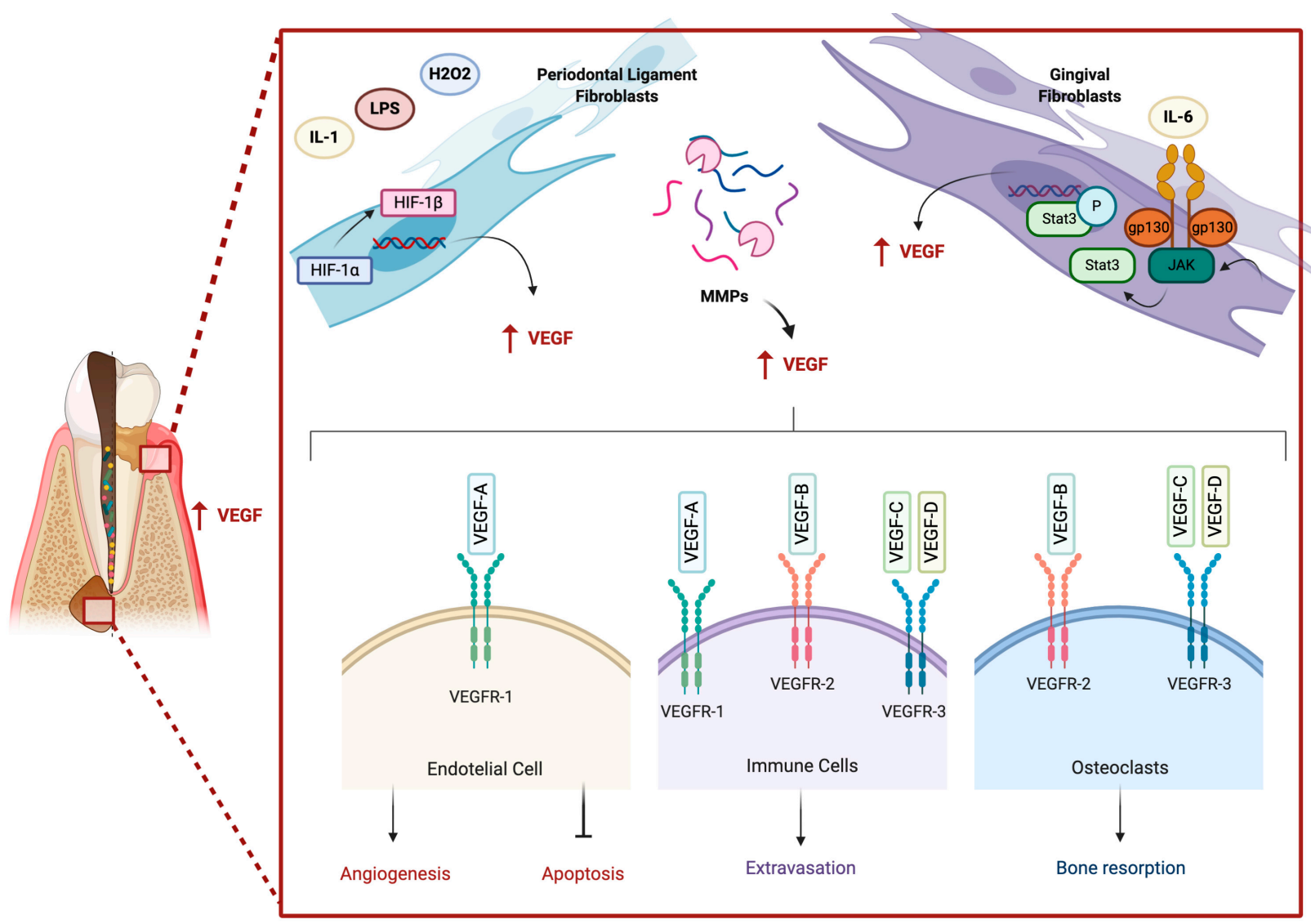

Figure 2. Role of VEGF in inflammatory periodontal diseases. During inflammatory periodontal diseases VEGF transcription can be induced by the activation of two pathways: (1) in periodontal fibroblasts IL-1, LPS and reactive oxygen species $\left(\mathrm{H}_{2} \mathrm{O}_{2}\right)$ may induce the transcription of VEGF through the activation of the HIF/VEGF pathway. (2) The formation of the complex IL-6/IL-6R/gp130 may activate JAK/STAT pathway enhancing the secretion of VEGF by gingival fibroblasts. Also, VEGF might be released through the MMP-mediated proteolytic cleavage from its cryptic forms from the extracellular matrix. These cellular pathways might result in the following effects: VEGF in endothelial cells inhibits apoptosis and VEGF-A/VEGFR-1 interaction induces angiogenesis in immune cells, VEGFs participates in leukocytes' extravasation and in osteoclasts VEGFR-2/-3 are associated with alveolar bone resorption. Created with Biorender.com. 


\subsection{Diagnostics}

Nowadays, the diagnosis of periodontitis, peri-implantitis and AP are mainly based on the clinical history, signs, symptoms and imaging exams. Nevertheless, these mostly reflect the history of past disease, but show important pitfalls to reflect present disease, early diagnosis and predict future disease progression [158,159]. Thereby, biomarker identification in oral fluids represents a future goal to aid clinical diagnosis.

Saliva and GCF are both oral fluids acknowledged to harvest biological markers from periodontal/peri-implant tissues with high potential for biomarker-based diagnostics. Nevertheless, VEGF studies in saliva of periodontitis patients are still controversial, possibly because of the complex nature of saliva $[57,58]$. Noticeably, a recent study evaluated the VEGF levels in whole saliva and serum samples from periodontitis and healthy individuals, considering the smoking habit. In general, higher levels of VEGF were found in saliva and serum levels of periodontitis group, but when stratified, this difference was confirmed only for smokers. The authors reported a diagnostic precision of 0.88 for VEGF to discriminate periodontitis individuals from healthy controls, supporting its diagnostic potential [59].

GCF is a physiologic transudate or inflammatory exudate that reflects health and diseased periodontal status, respectively. Several studies have reported higher levels of VEGF in GCF from periodontitis patients in relation to healthy individuals $[56,57,60,62,160,161]$ and reduction of its levels after conservative/non-surgical periodontal therapy $[60,160,161]$. However, no differences in its levels were found between periodontitis and healthy sites within the same periodontitis patients [61]. In an analogous manner to GCF, peri-implant crevicular fluid (PICF) reflects healthy and peri-implantitis tissues. Higher VEGF concentrations were detected in PICF from individuals with PI compared with clinically healthy implants, showing a strong correlation with pocket depth, suggesting that VEGF might participate in the progression of peri-implantitis [98]. In the same line, the combined detection of Treponema denticola together with IL-1 $\beta$, TIMP-2 and VEGF were reported to strengthen the ability to diagnose peri-implantitis sites and also to have the potential to predict disease outcome [63]. Another multi-biomarker study reported that VEGF, IL-17 and TNF alpha in PICF were able to differentiate healthy sites of healthy implants from peri-implantitis sites from diseased implants with a diagnostic precision of 0.90 . These outcomes propose that VEGF alone or combined with other biomarkers in GCF/PICF may aid to differentiate diseased sites [162].

Even though some investigations have proposed the analysis of the composition of GCF as a measurable method reflecting the presence and activity of ALEOs [163], up to now there is no available literature exploring whether oral fluids VEGF might serve as a biomarker in the diagnosis and prognosis of AP. A synthesis of the studies conducted in diagnostics of OSCC and inflammatory diseases affecting periodontal tissues is presented in Table 1.

\subsection{Therapy and Projections}

Given that periodontitis and peri-implantitis are chronic inflammatory pathologies characterized by bacterial triggering and the subsequent loss of attachment $[164,165]$, mechanical debridement on the root or implant surface is the gold standard of periodontal and peri-implantitis therapies, respectively. This intervention is successful for the majority of patients; nevertheless, some patients with severe periodontitis do not respond well enough. Patients with refractory disease, characterized by low plaque scores and poor response to therapy [166], might be candidates for immune modulation therapy. In a similar manner to periodontitis and peri-implantitis, the main goal of AP therapy is to eradicate the infection and prevent microorganisms from infecting or re-infecting the perirradicular tissues [167]. Given its high success rate ( $80 \%)$ [168], immunomodulatory therapy might be useful only in a small number of cases with persistent AP.

An in vitro study comparing periodontitis associated fibroblasts (PAF) with normal gingival fibroblasts demonstrated that VEGFR-1 mRNA was highly expressed in the former [169]. In the same study, the use of a specific VEGFR-1 inhibitor or its down regulation 
via RNAi, resulted in significantly increased tissue metalloproteinase inhibitors (TIMP)-1 and -2 , and the subsequent decrease in the collagen breakdown [169]. These results suggest VEGFR-1 as a novel target to treat individuals with severe or refractory periodontitis [169]. Conversely, in vivo evidence suggests that anti-VEGF-A modulation has not favorable outcomes for periodontitis or peri-implantitis. A recent study in a rice rat model, which tends to naturally develop localized periodontitis without external intervention, demonstrated that the use of anti-VEGF-A monotherapy resulted in an extensive inflammatory response, distinguished by extreme alveolar bone loss and fibrosis in comparison with the non-monotherapy group [87]. Similarly, rat-specific anti-VEGF-mostly useful for the blockage of VEGF-A-hindered bone healing and implant osseointegration [88].

The blockage of VEGF receptors in AP has been explored in an experimental rat [170]. In this study, the use of antibodies against VEGFR-2 and -3 and the combination of them, demonstrated an anti-inflammatory effect of VEGFR-2 and a pro-inflammatory response to combined signaling of VEGFR-2 and -3 [170]. In humans, suppressors of cytokine signaling (SOCS) attenuate the gene expression of inflammatory and bone resorptive cytokines in periapical diseases, acting as natural blockers of particular inflammatory pathways [171] Higher levels of SOC-1 and SOC-3 in human ALEOs showed a tendency to negatively correlate with their size [171]. SOC-3 has been associated with the blockage of Stat3 in the regulation pathway of VEGF [172].

Overall, VEGF might represent a therapeutic target candidate to interfere with the bone resorptive process, angiogenesis and immune response in periodontitis, peri-implantitis and AP. Nevertheless, based on its homeostatic and healing roles, which are also mediated by angiogenesis and migration/differentiation of osteoblastic progenitor cells [173,174], further studies are necessary to assess the plausibility and clinical outcomes of anti-VEGF therapy in these family of pathologies. A synthesis of the studies conducted in the therapeutics of OSCC inflammatory diseases affecting periodontal tissues is presented in Table 2.

\section{Conclusions}

It can be concluded that the VEGF/VEGFR pathway is an important angiogenic mechanism commonly overexpressed in oral cancer and inflammatory periodontal diseases. In oral malignancies, VEGF overexpression is associated with the development of nodal and distant metastases and poor outcome. In periodontitis, in addition of being associated with angiogenesis, it is also involved in the inflammatory and bone resorptive responses. VEGF has great potential to be used as diagnostic and prognostic biomarker, especially in oral cancer. However, more prospective multicenter studies are needed in order to validate its utility for these purposes. Finally, targeting angiogenesis as part of OSCC and periodontal inflammatory treatment might be a useful strategy, but more preclinic and clinical studies are needed before this can be translated into patient's care.

Author Contributions: S.N.: Conceptualization, text writing and revision, figures and tables design. A.F.: Conceptualization, text writing and revision, figures and tables design. M.J.B.: Conceptualization, text writing and revision, figures and tables design. M.H.: Conceptualization, text writing and revision, figures and tables design, manuscript editing. All authors have read and agreed to the published version of the manuscript.

Funding: This research was funded by National Fund for Scientific and Technological Development FONDECYT, grant number 1200098.

Institutional Review Board Statement: Not applicable.

Informed Consent Statement: Not applicable.

Data Availability Statement: Not applicable.

Acknowledgments: We want to thank Constanza Jiménez for her support in correcting English writing.

Conflicts of Interest: The authors declare no conflict of interest. 


\section{References}

1. Apte, R.S.; Chen, D.S.; Ferrara, N. VEGF in Signaling and Disease: Beyond Discovery and Development. Cell 2019, 176, 1248-1264. [CrossRef] [PubMed]

2. Gupta, B.; Chandra, S.; Raj, V.; Gupta, V. Immunohistochemical expression of vascular endothelial growth factor in orofacial lesions-A review. J. Oral Biol. Craniofac. Res. 2016, 6, 231-236. [CrossRef] [PubMed]

3. Ramakrishnan, S.; Anand, V.; Roy, S. Vascular endothelial growth factor signaling in hypoxia and inflammation. J. Neuroimmune Pharmacol. 2014, 9, 142-160. [CrossRef] [PubMed]

4. $\mathrm{Hu}, \mathrm{K} . ;$ Olsen, B.R. Vascular endothelial growth factor control mechanisms in skeletal growth and repair. Dev. Dyn. 2017, 246, 227-234. [CrossRef] [PubMed]

5. Shaik-Dasthagirisaheb, Y.B.; Varvara, G.; Murmura, G.; Saggini, A.; Potalivo, G.; Caraffa, A.; Antinolfi, P.; Tete, S.; Tripodi, D.; Conti, F.; et al. Vascular endothelial growth factor (VEGF), mast cells and inflammation. Int. J. Immunopathol. Pharmacol. 2013, 26, 327-335. [CrossRef] [PubMed]

6. Simons, M.; Gordon, E.; Claesson-Welsh, L. Mechanisms and regulation of endothelial VEGF receptor signalling. Nat. Rev. Mol. Cell Biol. 2016, 17, 611-625. [CrossRef] [PubMed]

7. Bray, F.; Ferlay, J.; Soerjomataram, I.; Siegel, R.L.; Torre, L.A.; Jemal, A. Global cancer statistics 2018: GLOBOCAN estimates of incidence and mortality worldwide for 36 cancers in 185 countries. CA Cancer J. Clin. 2018, 68, 394-424. [CrossRef]

8. Dhanuthai, K.; Rojanawatsirivej, S.; Thosaporn, W.; Kintarak, S.; Subarnbhesaj, A.; Darling, M.; Kryshtalskyj, E.; Chiang, C.P.; Shin, H.I.; Choi, S.Y.; et al. Oral cancer: A multicenter study. Med. Oral Patol. Oral Cir. Bucal 2018, 23, e23-e29. [CrossRef]

9. Torabi, S.J.; Benchetrit, L.; Kuo Yu, P.; Cheraghlou, S.; Savoca, E.L.; Tate, J.P.; Judson, B.L. Prognostic Case Volume Thresholds in Patients With Head and Neck Squamous Cell Carcinoma. JAMA Otolaryngol. Head Neck Surg. 2019, 145, 708-715. [CrossRef]

10. Dik, E.A.; Willems, S.M.; Ipenburg, N.A.; Rosenberg, A.J.; Van Cann, E.M.; van Es, R.J. Watchful waiting of the neck in early stage oral cancer is unfavourable for patients with occult nodal disease. Int. J. Oral Maxillofac. Surg. 2016, 45, 945-950. [CrossRef]

11. Speight, P.M.; Khurram, S.A.; Kujan, O. Oral potentially malignant disorders: Risk of progression to malignancy. Oral Surg. Oral Med. Oral Pathol. Oral Radiol. 2018, 125, 612-627. [CrossRef] [PubMed]

12. Hanahan, D.; Weinberg, R.A. Hallmarks of cancer: The next generation. Cell 2011, 144, 646-674. [CrossRef] [PubMed]

13. Folkman, J. What is the evidence that tumors are angiogenesis dependent? J. Natl. Cancer Inst. 1990, 82, 4-6. [CrossRef] [PubMed]

14. Sauter, E.R.; Nesbit, M.; Watson, J.C.; Klein-Szanto, A.; Litwin, S.; Herlyn, M. Vascular endothelial growth factor is a marker of tumor invasion and metastasis in squamous cell carcinomas of the head and neck. Clin. Cancer Res. 1999, 5, 775-782. [PubMed]

15. Ribatti, D.; Nico, B.; Crivellato, E.; Roccaro, A.M.; Vacca, A. The history of the angiogenic switch concept. Leukemia 2007, 21, 44-52. [CrossRef] [PubMed]

16. Lapeyre-Prost, A.; Terme, M.; Pernot, S.; Pointet, A.L.; Voron, T.; Tartour, E.; Taieb, J. Immunomodulatory Activity of VEGF in Cancer. Int. Rev. Cell Mol. Biol. 2017, 330, 295-342. [CrossRef] [PubMed]

17. Aguilar-Cazares, D.; Chavez-Dominguez, R.; Carlos-Reyes, A.; Lopez-Camarillo, C.; Hernadez de la Cruz, O.N.; Lopez-Gonzalez, J.S. Contribution of Angiogenesis to Inflammation and Cancer. Front. Oncol. 2019, 9, 1399. [CrossRef]

18. Chavakis, E.; Dimmeler, S. Regulation of Endothelial Cell Survival and Apoptosis During Angiogenesis. Arterioscler. Thromb. Vasc. Biol. 2002, 22, 887-893. [CrossRef]

19. Meng, Y.; Wang, W.; Kang, J.; Wang, X.; Sun, L. Role of the PI3K/AKT signalling pathway in apoptotic cell death in the cerebral cortex of streptozotocin-induced diabetic rats. Exp. Ther. Med. 2017, 13, 2417-2422. [CrossRef]

20. Gandolfo, M.; Keszler, A.; Lanfranchi, H.; Itoiz, M.E. Increased subepithelial vascularization and VEGF expression reveal potentially malignant changes in human oral mucosa lesions. Oral Surg. Oral Med. Oral Pathol. Oral Radiol. Endod. 2011, 111, 486-493. [CrossRef]

21. Nayak, S.; Goel, M.M.; Chandra, S.; Bhatia, V.; Mehrotra, D.; Kumar, S.; Makker, A.; Rath, S.K.; Agarwal, S.P. VEGF-A immunohistochemical and mRNA expression in tissues and its serum levels in potentially malignant oral lesions and oral squamous cell carcinomas. Oral Oncol. 2012, 48, 233-239. [CrossRef] [PubMed]

22. Seki, S.; Fujiwara, M.; Matsuura, M.; Fujita, S.; Ikeda, H.; Asahina, I.; Ikeda, T. Prediction of outcome of patients with oral squamous cell carcinoma using vascular invasion and the strongly positive expression of vascular endothelial growth factors. Oral Oncol. 2011, 47, 588-593. [CrossRef] [PubMed]

23. Patil, B.R.; Bhat, K.; Somannavar, P.; Hosmani, J.; Kotrashetti, V.; Nayak, R. Comparison of immunohistochemical expression of vascular endothelial growth factor and CD105 in oral squamous cell carcinoma: Its correlation with prognosis. J. Cancer Res. Ther. 2018, 14, 421-427. [CrossRef]

24. López de Cicco, R.; Watson, J.C.; Bassi, D.E.; Litwin, S.; Klein-Szanto, A.J. Simultaneous expression of furin and vascular endothelial growth factor in human oral tongue squamous cell carcinoma progression. Clin. Cancer Res. $2004,10,4480-4488$. [CrossRef] [PubMed]

25. Arora, S.; Kaur, J.; Sharma, C.; Mathur, M.; Bahadur, S.; Shukla, N.K.; Deo, S.V.; Ralhan, R. Stromelysin 3, Ets-1, and vascular endothelial growth factor expression in oral precancerous and cancerous lesions: Correlation with microvessel density, progression, and prognosis. Clin. Cancer Res. 2005, 11, 2272-2284. [CrossRef] [PubMed]

26. Johnstone, S.; Logan, R.M. Expression of vascular endothelial growth factor (VEGF) in normal oral mucosa, oral dysplasia and oral squamous cell carcinoma. Int. J. Oral Maxillofac. Surg. 2007, 36, 263-266. [CrossRef] 
27. Aggarwal, S.; Devaraja, K.; Sharma, S.C.; Das, S.N. Expression of vascular endothelial growth factor (VEGF) in patients with oral squamous cell carcinoma and its clinical significance. Clin. Chim. Acta 2014, 436, 35-40. [CrossRef]

28. Peterle, G.T.; Maia, L.L.; Trivilin, L.O.; de Oliveira, M.M.; Dos Santos, J.G.; Mendes, S.O.; Stur, E.; Agostini, L.P.; Rocha, L.A.; Moysés, R.A.; et al. PAI-1, CAIX, and VEGFA expressions as prognosis markers in oral squamous cell carcinoma. J. Oral. Pathol. Med. 2018, 47, 566-574. [CrossRef]

29. Faratzis, G.; Tsiambas, E.; Rapidis, A.D.; Machaira, A.; Xiromeritis, K.; Patsouris, E. VEGF and ki 67 expression in squamous cell carcinoma of the tongue: An immunohistochemical and computerized image analysis study. Oral Oncol. 2009, 45, 584-588. [CrossRef]

30. Shang, Z.J.; Li, Z.B.; Li, J.R. VEGF is up-regulated by hypoxic stimulation and related to tumour angiogenesis and severity of disease in oral squamous cell carcinoma: In vitro and in vivo studies. Int. J. Oral Maxillofac. Surg. 2006, 35, 533-538. [CrossRef]

31. Shao, Z.; Zhang, W.F.; Chen, X.M.; Shang, Z.J. Expression of EphA2 and VEGF in squamous cell carcinoma of the tongue: Correlation with the angiogenesis and clinical outcome. Oral Oncol. 2008, 44, 1110-1117. [CrossRef] [PubMed]

32. Morita, Y.; Morita, N.; Hata, K.; Nakanishi, M.; Kimoto, N.; Omata, T.; Nakamura, Y.; Yoneda, T. Cyclooxygenase-2 expression is associated with vascular endothelial growth factor-c and lymph node metastasis in human oral tongue cancer. Oral Surg. Oral Med. Oral Pathol. Oral Radiol. 2014, 117, 502-510. [CrossRef] [PubMed]

33. Shintani, S.; Li, C.; Ishikawa, T.; Mihara, M.; Nakashiro, K.; Hamakawa, H. Expression of vascular endothelial growth factor A, B, C, and D in oral squamous cell carcinoma. Oral Oncol. 2004, 40, 13-20. [CrossRef]

34. Pianka, A.; Knösel, T.; Probst, F.A.; Troeltzsch, M.; Woodlock, T.; Otto, S.; Ehrenfeld, M. Vascular endothelial growth factor receptor isoforms: Are they present in oral squamous cell carcinoma? J. Oral Maxillofac. Surg. 2015, 73, 897-904. [CrossRef] [PubMed]

35. Chien, M.-H.; Liu, Y.-F.; Hsin, C.-H.; Lin, C.-H.; Shih, C.-H.; Yang, S.-F.; Cheng, C.-W.; Lin, C.-W. Impact of VEGF-C Gene Polymorphisms and Environmental Factors on Oral Cancer Susceptibility in Taiwan. PLoS ONE 2013, 8, e60283. [CrossRef]

36. Supic, G.; Jovic, N.; Zeljic, K.; Kozomara, R.; Magic, Z. Association of VEGF-A genetic polymorphisms with cancer risk and survival in advanced-stage oral squamous cell carcinoma patients. Oral Oncol. 2012, 48, 1171-1177. [CrossRef]

37. Zhao, S.F.; Zhan, P.; Yang, X.D.; Lu, M.X.; Sun, G.W.; Wang, Y.X.; Zhang, Y.K.; Pu, Y.M.; Tang, E.Y. VEGF +936C/T and +460C/T gene polymorphisms and oral cancer risk: A meta-analysis. Mol. Biol. Rep. 2013, 40, 6637-6643. [CrossRef]

38. Lee, L.T.; Wong, Y.K.; Chan, M.Y.; Chang, K.W.; Chen, S.C.; Chang, C.T.; Wang, J. The correlation between HIF-1 alpha and VEGF in oral squamous cell carcinomas: Expression patterns and quantitative immunohistochemical analysis. J. Chin. Med. Assoc. 2018, 81, 370-375. [CrossRef]

39. Lin, Y.W.; Huang, S.T.; Wu, J.C.; Chu, T.H.; Huang, S.C.; Lee, C.C.; Tai, M.H. Novel HDGF/HIF-1 $\alpha /$ VEGF axis in oral cancer impacts disease prognosis. BMC Cancer 2019, 19, 1083. [CrossRef]

40. Bredell, M.G.; Ernst, J.; El-Kochairi, I.; Dahlem, Y.; Ikenberg, K.; Schumann, D.M. Current relevance of hypoxia in head and neck cancer. Oncotarget 2016, 7, 50781-50804. [CrossRef]

41. Pouysségur, J.; Dayan, F.; Mazure, N.M. Hypoxia signalling in cancer and approaches to enforce tumour regression. Nature 2006, 441, 437-443. [CrossRef] [PubMed]

42. Zhu, G.Q.; Tang, Y.L.; Li, L.; Zheng, M.; Jiang, J.; Li, X.Y.; Chen, S.X.; Liang, X.H. Hypoxia inducible factor $1 \alpha$ and hypoxia inducible factor $2 \alpha$ play distinct and functionally overlapping roles in oral squamous cell carcinoma. Clin. Cancer Res. 2010, 16, 4732-4741. [CrossRef] [PubMed]

43. Niu, G.; Wright, K.L.; Huang, M.; Song, L.; Haura, E.; Turkson, J.; Zhang, S.; Wang, T.; Sinibaldi, D.; Coppola, D.; et al. Constitutive Stat3 activity up-regulates VEGF expression and tumor angiogenesis. Oncogene 2002, 21, 2000-2008. [CrossRef] [PubMed]

44. Masuda, M.; Ruan, H.Y.; Ito, A.; Nakashima, T.; Toh, S.; Wakasaki, T.; Yasumatsu, R.; Kutratomi, Y.; Komune, S.; Weinstein, I.B. Signal transducers and activators of transcription 3 up-regulates vascular endothelial growth factor production and tumor angiogenesis in head and neck squamous cell carcinoma. Oral Oncol. 2007, 43, 785-790. [CrossRef]

45. Wang, Y.H.; Wu, M.W.; Yang, A.K.; Zhang, W.D.; Sun, J.; Liu, T.R.; Chen, Y.F. COX-2 Gene increases tongue cancer cell proliferation and invasion through VEGF-C pathway. Med. Oncol. 2011, 28 (Suppl. S1), S360-S366. [CrossRef]

46. Kono, M.; Watanabe, M.; Abukawa, H.; Hasegawa, O.; Satomi, T.; Chikazu, D. Cyclo-oxygenase-2 expression is associated with vascular endothelial growth factor $\mathrm{C}$ expression and lymph node metastasis in oral squamous cell carcinoma. J. Oral Maxillofac. Surg. 2013, 71, 1694-1702. [CrossRef]

47. Shang, Z.J.; Li, J.R.; Li, Z.B. Upregulation of serum and tissue vascular endothelial growth factor correlates with angiogenesis and prognosis of oral squamous cell carcinoma. J. Oral Maxillofac. Surg. 2007, 65, 17-21. [CrossRef]

48. Tse, G.M.; Chan, A.W.; Yu, K.H.; King, A.D.; Wong, K.T.; Chen, G.G.; Tsang, R.K.; Chan, A.B. Strong immunohistochemical expression of vascular endothelial growth factor predicts overall survival in head and neck squamous cell carcinoma. Ann. Surg. Oncol. 2007, 14, 3558-3565. [CrossRef]

49. Patel, K.R.; Vajaria, B.N.; Begum, R.; Patel, J.B.; Shah, F.D.; Joshi, G.M.; Patel, P.S. VEGFA isoforms play a vital role in oral cancer progression. Tumour Biol. 2015, 36, 6321-6332. [CrossRef]

50. Almangush, A.; Heikkinen, I.; Mäkitie, A.A.; Coletta, R.D.; Läärä, E.; Leivo, I.; Salo, T. Prognostic biomarkers for oral tongue squamous cell carcinoma: A systematic review and meta-analysis. Br. J. Cancer 2017, 117, 856-866. [CrossRef] 
51. Kazakydasan, S.; Rahman, Z.A.; Ismail, S.M.; Abraham, M.T.; Kallarakkal, T.G. Prognostic significance of VEGF-C in predicting micrometastasis and isolated tumour cells in N0 oral squamous cell carcinoma. J. Oral Pathol. Med. 2017, 46, 194-200. [CrossRef] [PubMed]

52. Matsui, T.; Shigeta, T.; Umeda, M.; Komori, T. Vascular endothelial growth factor C (VEGF-C) expression predicts metastasis in tongue cancer. Oral Surg. Oral Med. Oral Pathol. Oral Radiol. 2015, 120, 436-442. [CrossRef] [PubMed]

53. Wakisaka, N.; Hasegawa, Y.; Yoshimoto, S.; Miura, K.; Shiotani, A.; Yokoyama, J.; Sugasawa, M.; Moriyama-Kita, M.; Endo, K.; Yoshizaki, T. Primary Tumor-Secreted Lymphangiogenic Factors Induce Pre-Metastatic Lymphvascular Niche Formation at Sentinel Lymph Nodes in Oral Squamous Cell Carcinoma. PLoS ONE 2015, 10, e0144056. [CrossRef]

54. Naruse, T.; Yanamoto, S.; Yamada, S.I.; Takahashi, H.; Matsushita, Y.; Imayama, N.; Ikeda, H.; Shiraishi, T.; Fujita, S.; Ikeda, T.; et al. Immunohistochemical study of vascular endothelial growth factor-C/vascular endothelial growth factor receptor-3 expression in oral tongue squamous cell carcinoma: Correlation with the induction of lymphangiogenesis. Oncol. Lett. 2015, 10, $2027-2034$. [CrossRef] [PubMed]

55. Al-Shareef, H.; Hiraoka, S.I.; Tanaka, N.; Shogen, Y.; Lee, A.D.; Bakhshishayan, S.; Kogo, M. Use of NRP1, a novel biomarker, along with VEGF-C, VEGFR-3, CCR7 and SEMA3E, to predict lymph node metastasis in squamous cell carcinoma of the tongue. Oncol. Rep. 2016, 36, 2444-2454. [CrossRef] [PubMed]

56. Booth, V.; Young, S.; Cruchley, A.; Taichman, N.S.; Paleolog, E. Vascular endothelial growth factor in human periodontal disease. J. Periodontal Res. 1998, 33, 491-499. [CrossRef] [PubMed]

57. Afacan, B.; Ozturk, V.O.; Pasali, C.; Bozkurt, E.; Kose, T.; Emingil, G. Gingival crevicular fluid and salivary HIF-1alpha, VEGF, and TNF-alpha levels in periodontal health and disease. J. Periodontol. 2019, 90, 788-797. [CrossRef] [PubMed]

58. Sosnin, D.Y.; Gileva, O.S.; Sivak, E.Y.; Daurova, F.Y.; Gibadullina, N.V.; Korotin, S.V. The content of vascular endothelial growth factor in saliva and serum in patients with periodontitis. Klin. Lab. Diagn. 2019, 64, 663-668. [CrossRef]

59. Şaştım, Ç.; Gürsoy, M.; Könönen, E.; Kasurinen, A.; Norvio, S.; Gürsoy, U.K.; Doğan, B. Salivary and serum markers of angiogenesis in periodontitis in relation to smoking. Clin. Oral. Investig. 2020, 10.1007/s00784-020-03411-4. [CrossRef]

60. Romano, F.; Bongiovanni, L.; Bianco, L.; Di Scipio, F.; Yang, Z.; Sprio, A.E.; Berta, G.N.; Aimetti, M. Biomarker levels in gingival crevicular fluid of generalized aggressive periodontitis patients after non-surgical periodontal treatment. Clin. Oral Investig. 2018, 22, 1083-1092. [CrossRef]

61. Zekeridou, A.; Giannopoulou, C.; Cancela, J.; Courvoisier, D.; Mombelli, A. Effect of initial periodontal therapy on gingival crevicular fluid cytokine profile in subjects with chronic periodontitis. Clin. Exp. Dent. Res. 2017, 3, 62-68. [CrossRef]

62. Tayman, M.A.; Kurgan, S.; Onder, C.; Guney, Z.; Serdar, M.A.; Kantarci, A.; Gunhan, M. A disintegrin-like and metalloproteinase with thrombospondin-1 (ADAMTS-1) levels in gingival crevicular fluid correlate with vascular endothelial growth factor-A, hypoxia-inducible factor-1alpha, and clinical parameters in patients with advanced periodontitis. J. Periodontol. 2019, 90, 1182-1189. [CrossRef] [PubMed]

63. Wang, H.L.; Garaicoa-Pazmino, C.; Collins, A.; Ong, H.S.; Chudri, R.; Giannobile, W.V. Protein biomarkers and microbial profiles in peri-implantitis. Clin. Oral Implants Res. 2016, 27, 1129-1136. [CrossRef]

64. Graziani, F.; Vano, M.; Viacava, P.; Itro, A.; Tartaro, G.; Gabriele, M. Microvessel density and vascular endothelial growth factor (VEGF) expression in human radicular cysts. Am. J. Dent. 2006, 19, 11-14. [PubMed]

65. Fonseca-Silva, T.; Santos, C.; Alves, L.; Dias, L.; Brito-Júnior, M.; De Paula, A.; Guimarães, A. Detection and quantification of mast cell, vascular endothelial growth factor, and microvessel density in human inflammatory periapical cysts and granulomas. Int. Endod. J. 2012, 45, 859-864. [CrossRef] [PubMed]

66. Virtej, A.; Løes, S.S.; Berggreen, E.; Bletsa, A. Localization and signaling patterns of vascular endothelial growth factors and receptors in human periapical lesions. J. Endod. 2013, 39, 605-611. [CrossRef] [PubMed]

67. Fernández, A.; Veloso, P.; Astorga, J.; Rodríguez, C.; Torres, V.A.; Valdés, M.; Garrido, M.; Gebicke-Haerter, P.J.; Hernández, M. Epigenetic regulation of TLR2-mediated periapical inflammation. Int. Endod. J. 2020, 53, 1229-1237. [CrossRef]

68. Viallard, C.; Larrivée, B. Tumor angiogenesis and vascular normalization: Alternative therapeutic targets. Angiogenesis 2017, 20, 409-426. [CrossRef]

69. Carmeliet, P.; Jain, R.K. Molecular mechanisms and clinical applications of angiogenesis. Nature 2011, 473, 298-307. [CrossRef]

70. Matsuura, M.; Onimaru, M.; Yonemitsu, Y.; Suzuki, H.; Nakano, T.; Ishibashi, H.; Shirasuna, K.; Sueishi, K. Autocrine loop between vascular endothelial growth factor (VEGF)-C and VEGF receptor-3 positively regulates tumor-associated lymphangiogenesis in oral squamoid cancer cells. Am. J. Pathol. 2009, 175, 1709-1721. [CrossRef]

71. Okada, Y.; Ueno, H.; Katagiri, M.; Oneyama, T.; Shimomura, K.; Sakurai, S.; Mataga, I.; Moride, M.; Hasegawa, H. Experimental study of antiangiogenic gene therapy targeting VEGF in oral cancer. Odontology 2010, 98, 52-59. [CrossRef] [PubMed]

72. Hwang-Bo, J.; Bae, M.G.; Park, J.H.; Chung, I.S. 3-O-Acetyloleanolic acid inhibits VEGF-A-induced lymphangiogenesis and lymph node metastasis in an oral cancer sentinel lymph node animal model. BMC Cancer 2018, 18, 714. [CrossRef] [PubMed]

73. Ganjibakhsh, M.; Monshizadeh, R.; Nasimian, A.; Aminishakib, P.; Farzaneh, P.; Tavakoli Shiraji, S.; Gharajei, A.; Rahrotaban, S.; Baghaei, F.; Gohari, N.S. Anti-angiogenic efficacy of aflibercept and bevacizumab in primary oral squamous cell carcinoma cells. J. Oral Pathol. Med. 2018, 47, 575-582. [CrossRef] [PubMed]

74. Liu, L.; Chen, J.; Cai, X.; Yao, Z.; Huang, J. Progress in targeted therapeutic drugs for oral squamous cell carcinoma. Surg Oncol 2019, 31, 90-97. [CrossRef] 
75. Ferrara, N.; Adamis, A.P. Ten years of anti-vascular endothelial growth factor therapy. Nat. Rev. Drug Discov. 2016, 15, 385-403. [CrossRef]

76. Cohen, E.E.; Davis, D.W.; Karrison, T.G.; Seiwert, T.Y.; Wong, S.J.; Nattam, S.; Kozloff, M.F.; Clark, J.I.; Yan, D.H.; Liu, W.; et al. Erlotinib and bevacizumab in patients with recurrent or metastatic squamous-cell carcinoma of the head and neck: A phase I/II study. Lancet Oncol. 2009, 10, 247-257. [CrossRef]

77. Argiris, A.; Karamouzis, M.V.; Gooding, W.E.; Branstetter, B.F.; Zhong, S.; Raez, L.E.; Savvides, P.; Romkes, M. Phase II trial of pemetrexed and bevacizumab in patients with recurrent or metastatic head and neck cancer. J. Clin. Oncol. 2011, 29, 1140-1145. [CrossRef]

78. Fury, M.G.; Xiao, H.; Sherman, E.J.; Baxi, S.; Smith-Marrone, S.; Schupak, K.; Gewanter, R.; Gelblum, D.; Haque, S.; Schoder, H.; et al. Phase II trial of bevacizumab + cetuximab + cisplatin with concurrent intensity-modulated radiation therapy for patients with stage III/IVB head and neck squamous cell carcinoma. Head Neck 2016, 38 (Suppl. S1), E566-E570. [CrossRef]

79. Argiris, A.; Li, S.; Savvides, P.; Ohr, J.P.; Gilbert, J.; Levine, M.A.; Chakravarti, A.; Haigentz, M., Jr.; Saba, N.F.; Ikpeazu, C.V.; et al. Phase III Randomized Trial of Chemotherapy With or Without Bevacizumab in Patients With Recurrent or Metastatic Head and Neck Cancer. J. Clin. Oncol. 2019, 37, 3266-3274. [CrossRef]

80. Möckelmann, N.; Rieckmann, T.; Busch, C.J.; Becker, B.; Gleißner, L.; Hoffer, K.; Omniczynski, M.; Steinmeister, L.; Laban, S.; Grénman, R.; et al. Effect of sorafenib on cisplatin-based chemoradiation in head and neck cancer cells. Oncotarget 2016, 7, 23542-23551. [CrossRef]

81. Beizaei, K.; Gleißner, L.; Hoffer, K.; Bußmann, L.; Vu, A.T.; Steinmeister, L.; Laban, S.; Möckelmann, N.; Münscher, A.; Petersen, C.; et al. Receptor tyrosine kinase MET as potential target of multi-kinase inhibitor and radiosensitizer sorafenib in HNSCC. Head Neck 2019, 41, 208-215. [CrossRef] [PubMed]

82. Williamson, S.K.; Moon, J.; Huang, C.H.; Guaglianone, P.P.; LeBlanc, M.; Wolf, G.T.; Urba, S.G. Phase II evaluation of sorafenib in advanced and metastatic squamous cell carcinoma of the head and neck: Southwest Oncology Group Study S0420. J. Clin. Oncol. 2010, 28, 3330-3335. [CrossRef] [PubMed]

83. Lalami, Y.; Garcia, C.; Flamen, P.; Ameye, L.; Paesmans, M.; Awada, A. Phase II trial evaluating the efficacy of sorafenib (BAY 43-9006) and correlating early fluorodeoxyglucose positron emission tomography-CT response to outcome in patients with recurrent and/or metastatic head and neck cancer. Head Neck 2016, 38, 347-354. [CrossRef] [PubMed]

84. Gilbert, J.; Schell, M.J.; Zhao, X.; Murphy, B.; Tanvetyanon, T.; Leon, M.E.; Neil Hayes, D.; Haigentz, M., Jr.; Saba, N.; Nieva, J.; et al. A randomized phase II efficacy and correlative studies of cetuximab with or without sorafenib in recurrent and/or metastatic head and neck squamous cell carcinoma. Oral Oncol. 2015, 51, 376-382. [CrossRef]

85. Zhou, G.; Hasina, R.; Wroblewski, K.; Mankame, T.P.; Doçi, C.L.; Lingen, M.W. Dual inhibition of vascular endothelial growth factor receptor and epidermal growth factor receptor is an effective chemopreventive strategy in the mouse 4-NQO model of oral carcinogenesis. Cancer Prev. Res. 2010, 3, 1493-1502. [CrossRef]

86. Limaye, S.; Riley, S.; Zhao, S.; O’Neill, A.; Posner, M.; Adkins, D.; Jaffa, Z.; Clark, J.; Haddad, R. A randomized phase II study of docetaxel with or without vandetanib in recurrent or metastatic squamous cell carcinoma of head and neck (SCCHN). Oral Oncol. 2013, 49, 835-841. [CrossRef]

87. Messer, J.G.; Castillo, E.J.; Abraham, A.M.; Jiron, J.M.; Israel, R.; Yarrow, J.F.; Thomas, S.; Reynolds, M.C.; Wnek, R.D.; Jorgensen, M.; et al. Anti-vascular endothelial growth factor antibody monotherapy causes destructive advanced periodontitis in rice rats (Oryzomys palustris). Bone 2020, 130, 115141. [CrossRef]

88. Al Subaie, A.E.; Eimar, H.; Abdallah, M.-N.; Durand, R.; Feine, J.; Tamimi, F.; Emami, E. Anti-VEGFs hinder bone healing and implant osseointegration in rat tibiae. J. Clin. Periodontol. 2015, 42, 688-696. [CrossRef]

89. Onabolu, O.; Donos, N.; Tu, Y.K.; Darbar, U.; Nibali, L. Periodontal progression based on radiographic records: An observational study in chronic and aggressive periodontitis. J. Dent. 2015, 43, 673-682. [CrossRef]

90. Garrido, M.; Cardenas, A.M.; Astorga, J.; Quinlan, F.; Valdes, M.; Chaparro, A.; Carvajal, P.; Pussinen, P.; Huaman-Chipana, P.; Jalil, J.E.; et al. Elevated Systemic Inflammatory Burden and Cardiovascular Risk in Young Adults with Endodontic Apical Lesions. J. Endod. 2019, 45, 111-115. [CrossRef]

91. Kulakov, A.A.; Kogan, E.A.; Brailovskaya, T.V.; Vedyaeva, A.P.; Zharkov, N.V. Morphological and Molecular-Biological Features of Inflammatory and Regeneratory Processes in Peridont Tissues with Periimplantitis and Periodontitis. Dokl. Biochem. Biophys. 2020, 492, 142-146. [CrossRef] [PubMed]

92. Decker, C.G.; Wang, Y.; Paluck, S.J.; Shen, L.; Loo, J.A.; Levine, A.J.; Miller, L.S.; Maynard, H.D. Fibroblast growth factor 2 dimer with superagonist in vitro activity improves granulation tissue formation during wound healing. Biomaterials 2016, 81, 157-168. [CrossRef] [PubMed]

93. Vladau, M.; Cimpean, A.M.; Balica, R.A.; Jitariu, A.A.; Popovici, R.A.; Raica, M. VEGF/VEGFR2 Axis in Periodontal Disease Progression and Angiogenesis: Basic Approach for a New Therapeutic Strategy. In Vivo 2016, 30, 53-60. [PubMed]

94. Dhir, S.; Kumar, V. Are cardiovascular risk parameters and glycemic levels associated with periodontitis in type 2 diabetes patients? A clinical study. Indian Heart J. 2018, 70, 430-432. [CrossRef]

95. Preus, H.R.; Dahlen, G.; Gjermo, P.; Baelum, V. Microbiologic Observations After Four Treatment Strategies Among Patients With Periodontitis Maintaining a High Standard of Oral Hygiene: Secondary Analysis of a Randomized Controlled Clinical Trial. J. Periodontol. 2015, 86, 856-865. [CrossRef] 
96. Alvarez, C.; Monasterio, G.; Cavalla, F.; Cordova, L.A.; Hernandez, M.; Heymann, D.; Garlet, G.P.; Sorsa, T.; Parnanen, P.; Lee, H.M.; et al. Osteoimmunology of Oral and Maxillofacial Diseases: Translational Applications Based on Biological Mechanisms. Front. Immunol. 2019, 10, 1664. [CrossRef]

97. Bullon, P.; Fioroni, M.; Goteri, G.; Rubini, C.; Battino, M. Immunohistochemical analysis of soft tissues in implants with healthy and peri-implantitis condition, and aggressive periodontitis. Clin. Oral. Implants Res. 2004, 15, 553-559. [CrossRef]

98. Mierzwinska-Nastalska, E.; Lomzynski, L.; Jaworska-Zaremba, M.; Kostrzewa-Janicka, J. Vascular endothelial growth factor in gingival crevicular fluid around dental implants. Eur. J. Med. Res. 2010, 15 (Suppl. S2), 88-91. [CrossRef]

99. Penmetsa, G.S.; Baddam, S.; Manyam, R.; Dwarakanath, C.D. Comparison of the number of gingival blood vessels between type 2 diabetes mellitus and chronic periodontitis patients: An immunohistological study. J. Indian Soc. Periodontol. 2015, 19, 164-168. [CrossRef]

100. Johnson, R.B.; Serio, F.G.; Dai, X. Vascular Endothelial Growth Factors and Progression of Periodontal Diseases. J. Periodontol. 1999, 70, 848-852. [CrossRef]

101. Egelberg, J. The blood vessels of the dento-gingival junction. J. Periodontal Res. 1966, 1, 163-179. [CrossRef] [PubMed]

102. Vasconcelos, R.C.; Costa Ade, L.; Freitas Rde, A.; Bezerra, B.A.; Santos, B.R.; Pinto, L.P.; Gurgel, B.C. Immunoexpression of HIF-1alpha and VEGF in Periodontal Disease and Healthy Gingival Tissues. Braz. Dent. J. 2016, 27, 117-122. [CrossRef] [PubMed]

103. Kranti, K.; Mani, R.; Elizabeth, A. Immunoexpression of vascular endothelial growth factor and Ki-67 in human gingival samples: An observational study. Indian J. Dent. 2015, 6, 69-74. [CrossRef] [PubMed]

104. Ianni, M.; Bruzzesi, G.; Pugliese, D.; Porcellini, E.; Carbone, I.; Schiavone, A.; Licastro, F. Variations in inflammatory genes are associated with periodontitis. Immun. Ageing 2013, 10, 39. [CrossRef] [PubMed]

105. Mazurek-Mochol, M.; Łagocka, R.; Dembowska, E.; Kozak, M.; Sawczuk, M.; Maciejewska, A.; Malinowski, D.; Safranow, K.; Pawlik, A. Lack of Association Between the VEGFA Gene Rs699947 Polymorphism and Periodontal Disease. Oral Health Prev. Dent. 2020, 18, 171-175. [CrossRef] [PubMed]

106. Lucarini, G.; Zizzi, A.; Rubini, C.; Ciolino, F.; Aspriello, S.D. VEGF, Microvessel Density, and CD44 as Inflammation Markers in Peri-implant Healthy Mucosa, Peri-implant Mucositis, and Peri-implantitis: Impact of Age, Smoking, PPD, and Obesity. Inflammation 2019, 42, 682-689. [CrossRef] [PubMed]

107. Cornelini, R.; Artese, L.; Rubini, C.; Fioroni, M.; Ferrero, G.; Santinelli, A.; Piattelli, A. Vascular endothelial growth factor and microvessel density around healthy and failing dental implants. Int. J. Oral Maxillofac. Implants 2001, 16, 389-393.

108. Papadakou, P.; Bletsa, A.; Yassin, M.A.; Karlsen, T.V.; Wiig, H.; Berggreen, E. Role of Hyperplasia of Gingival Lymphatics in Periodontal Inflammation. J. Dent. Res. 2017, 96, 467-476. [CrossRef]

109. Bletsa, A.; Abdalla, H.; Løes, S.; Berggreen, E. Lymphatic growth factors are expressed in human gingiva and upregulated in gingival fibroblasts after stimulation. J. Periodontol. 2018, 89, 606-615. [CrossRef]

110. Hou, C.; Tang, K.L.; Yang, P.S.; Zhang, P.P.; Sun, J.; Li, S. Effect of hypoxia on the expression of HIF-1alpha and VEGF in human periodontal ligament cells in vitro. Shanghai Kou Qiang Yi Xue 2010, 19, 329-334.

111. Li, J.-P.; Li, F.Y.L.; Xu, A.; Cheng, B.; Tsao, S.W.; Fung, M.-L.; Leung, W.K. Lipopolysaccharide and Hypoxia-Induced HIF-1 Activation in Human Gingival Fibroblasts. J. Periodontol. 2012, 83, 816-824. [CrossRef] [PubMed]

112. Kifune, T.; Ito, H.; Ishiyama, M.; Iwasa, S.; Takei, H.; Hasegawa, T.; Asano, M.; Shirakawa, T. Hypoxia-induced upregulation of angiogenic factors in immortalized human periodontal ligament fibroblasts. J. Oral Sci. 2018, 60, 519-525. [CrossRef] [PubMed]

113. Savita, A.; Sarun, E.; Arora, S.; Krishnan, S. Evaluation of glutathione level in gingival crevicular fluid in periodontal health, in chronic periodontitis and after nonsurgical periodontal therapy: A clinicobiochemical study. Contemp. Clin. Dent. 2015, 6, 206-210. [CrossRef] [PubMed]

114. Yamamoto, S.; Omori, K.; Mandai, H.; Nakayama, M.; Nakagawa, S.; Kobayashi, H.; Kunimine, T.; Yoshimura, H.; Sakaida, K.; Sako, H.; et al. Fungal metabolite (+)-terrein suppresses IL-6/sIL-6R-induced CSF1 secretion by inhibiting JAK1 phosphorylation in human gingival fibroblasts. Heliyon 2018, 4, e00979. [CrossRef] [PubMed]

115. Ng, K.T.; Li, J.P.; Ng, K.M.; Tipoe, G.L.; Leung, W.K.; Fung, M.L. Expression of hypoxia-inducible factor-1alpha in human periodontal tissue. J. Periodontol. 2011, 82, 136-141. [CrossRef] [PubMed]

116. Palwankar, P.; Rana, M.; Arora, K.; Deepthy, C. Evaluation of non-surgical therapy on glutathione levels in chronic periodontitis. Eur. J. Dent. 2015, 09, 415-422. [CrossRef] [PubMed]

117. Cavalla, F.; Osorio, C.; Paredes, R.; Valenzuela, M.A.; Garcia-Sesnich, J.; Sorsa, T.; Tervahartiala, T.; Hernandez, M. Matrix metalloproteinases regulate extracellular levels of SDF-1/CXCL12, IL-6 and VEGF in hydrogen peroxide-stimulated human periodontal ligament fibroblasts. Cytokine 2015, 73, 114-121. [CrossRef]

118. Takada, Y.; Mukhopadhyay, A.; Kundu, G.C.; Mahabeleshwar, G.H.; Singh, S.; Aggarwal, B.B. Hydrogen peroxide activates NFkappa B through tyrosine phosphorylation of I kappa B alpha and serine phosphorylation of p65: Evidence for the involvement of I kappa B alpha kinase and Syk protein-tyrosine kinase. J. Biol. Chem. 2003, 278, 24233-24241. [CrossRef]

119. Gloire, G.; Piette, J. Redox Regulation of Nuclear Post-Translational Modifications During NF-kB Activation. Antioxid. Redox Signal. 2009, 11, 2209-2222. [CrossRef]

120. Chaparro, A.; Sanz, A.; Quintero, A.; Inostroza, C.; Ramirez, V.; Carrion, F.; Figueroa, F.; Serra, R.; Illanes, S.E. Increased inflammatory biomarkers in early pregnancy is associated with the development of pre-eclampsia in patients with periodontitis: A case control study. J. Periodontal Res. 2013, 48, 302-307. [CrossRef] 
121. Konig, M.F.; Abusleme, L.; Reinholdt, J.; Palmer, R.J.; Teles, R.P.; Sampson, K.; Rosen, A.; Nigrovic, P.A.; Sokolove, J.; Giles, J.T.; et al. Aggregatibacter actinomycetemcomitans-induced hypercitrullination links periodontal infection to autoimmunity in rheumatoid arthritis. Sci. Transl. Med. 2016, 8, 369ra176. [CrossRef] [PubMed]

122. Chen, C.K.; Wu, Y.T.; Chang, Y.C. Association between chronic periodontitis and the risk of Alzheimer's disease: A retrospective, population-based, matched-cohort study. Alzheimers Res. Ther. 2017, 9, 56. [CrossRef] [PubMed]

123. Cannizzaro, M.V.; Marchetti, E.; Babino, G.; Del Duca, E.; Lechiancole, S.; Giunta, A.; Bianchi, L.; Esposito, M. Association between psoriasis and periodontitis, and efficacy of anti-TNF-alpha therapy: A case series. G Ital. Dermatol. Venereol. 2018. [CrossRef]

124. Aspriello, S.D.; Zizzi, A.; Lucarini, G.; Rubini, C.; Faloia, E.; Boscaro, M.; Tirabassi, G.; Piemontese, M. Vascular endothelial growth factor and microvessel density in periodontitis patients with and without diabetes. J. Periodontol. 2009, 80, 1783-1789. [CrossRef]

125. Lucarini, G.; Zizzi, A.; Aspriello, S.D.; Ferrante, L.; Tosco, E.; Lo Muzio, L.; Foglini, P.; Mattioli-Belmonte, M.; Di Primio, R.; Piemontese, M. Involvement of vascular endothelial growth factor, CD44 and CD133 in periodontal disease and diabetes: An immunohistochemical study. J. Clin. Periodontol. 2009, 36, 3-10. [CrossRef]

126. Ramya; Kumar, S. Expression of VEGF in Periodontal Tissues of Type II Diabetes Mellitus Patients with Chronic Periodontitis -an Immunohistochemical Study. J. Clin. Diagn. Res. 2014, 8, Zc01-Zc03. [CrossRef]

127. Mohamed, H.G.; Idris, S.B.; Ahmed, M.F.; Astrom, A.N.; Mustafa, K.; Ibrahim, S.O.; Mustafa, M. Influence of type 2 diabetes on local production of inflammatory molecules in adults with and without chronic periodontitis: A cross-sectional study. BMC Oral Health 2015, 15, 86. [CrossRef]

128. Nardi, G.M.; Ferrara, E.; Converti, I.; Cesarano, F.; Scacco, S.; Grassi, R.; Gnoni, A.; Grassi, F.R.; Rapone, B. Does Diabetes Induce the Vascular Endothelial Growth Factor (VEGF) Expression in Periodontal Tissues? A Systematic Review. Int. J. Environ. Res. Public Health 2020, 17, 2765. [CrossRef]

129. Zhu, H.; Lin, X.; Zheng, P.; Chen, H. Inflammatory cytokine levels in patients with periodontitis and/or coronary heart disease. Int. J. Clin. Exp. Pathol. 2015, 8, 2214-2220.

130. Widen, C.; Holmer, H.; Coleman, M.; Tudor, M.; Ohlsson, O.; Sattlin, S.; Renvert, S.; Persson, G.R. Systemic inflammatory impact of periodontitis on acute coronary syndrome. J. Clin. Periodontol. 2016, 43, 713-719. [CrossRef]

131. Stashenko, P.; Teles, R.; d'Souza, R. Periapical inflammatory responses and their modulation. Crit. Rev. Oral Biol. Med. 1998, 9, 498-521. [CrossRef] [PubMed]

132. Georgiou, A.C.; Crielaard, W.; Armenis, I.; de Vries, R.; van der Waal, S.V. Apical Periodontitis Is Associated with Elevated Concentrations of Inflammatory Mediators in Peripheral Blood: A Systematic Review and Meta-analysis. J. Endod. 2019, 45, 1279-1295.e1273. [CrossRef] [PubMed]

133. Tonnesen, M.G.; Feng, X.; Clark, R.A.F. Angiogenesis in Wound Healing. J. Investig. Dermatol. Symp. Proc. 2000, 5, 40-46. [CrossRef] [PubMed]

134. Márton, I.J.; Kiss, C. Overlapping protective and destructive regulatory pathways in apical periodontitis. J. Endod. 2014, 40, 155-163. [CrossRef] [PubMed]

135. Ferrero-Miliani, L.; Nielsen, O.; Andersen, P.; Girardin, S. Chronic inflammation: Importance of NOD2 and NALP3 in interleukin$1 \beta$ generation. Clin. Exp. Immunol. 2007, 147, 227-235. [CrossRef] [PubMed]

136. Nonaka, C.F.W.; Maia, A.P.; do Nascimento, G.J.F.; de Almeida Freitas, R.; de Souza, L.B.; Galvão, H.C. Immunoexpression of vascular endothelial growth factor in periapical granulomas, radicular cysts, and residual radicular cysts. Oral Surg. Oral Med. Oral Pathol. Oral Radiol. Endodontol. 2008, 106, 896-902. [CrossRef]

137. Tsai, C.H.; Weng, S.F.; Yang, L.C.; Huang, F.M.; Chen, Y.J.; Chang, Y.C. Immunohistochemical localization of tissue-type plasminogen activator and type I plasminogen activator inhibitor in radicular cysts. J. Oral Pathol. Med. 2004, 33, 156-161. [CrossRef]

138. Yang, Z.; Mo, X.; Gong, Q.; Pan, Q.; Yang, X.; Cai, W.; Li, C.; Ma, J.-X.; He, Y.; Gao, G. Critical effect of VEGF in the process of endothelial cell apoptosis induced by high glucose. Apoptosis 2008, 13, 1331-1343. [CrossRef]

139. Meeson, A.P.; Argilla, M.; Ko, K.; Witte, L.; Lang, R.A. VEGF deprivation-induced apoptosis is a component of programmed capillary regression. Development 1999, 126, 1407-1415.

140. Gupta, K.; Kshirsagar, S.; Li, W.; Gui, L.; Ramakrishnan, S.; Gupta, P.; Law, P.Y.; Hebbel, R.P. VEGF Prevents Apoptosis of Human Microvascular Endothelial Cells via Opposing Effects on MAPK/ERK and SAPK/JNK Signaling. Exp. Cell Res. 1999, 247, 495-504. [CrossRef]

141. Jakovljevic, A.; Knezevic, A.; Karalic, D.; Soldatovic, I.; Popovic, B.; Milasin, J.; Andric, M. Pro-inflammatory cytokine levels in human apical periodontitis: Correlation with clinical and histological findings. Aust. Endod. J. 2015, $41,72-77$. [CrossRef] [PubMed]

142. Ruiz, P.A.; de Toledo, O.A.; Pinto, L.P.; de Souza, L.B. Immunohistochemical expression of vascular endothelial growth factor and matrix metalloproteinase-9 in radicular and residual radicular cysts. J. Appl. Oral Sci. 2010, 18, 613-620. [CrossRef] [PubMed]

143. Leonardi, R.; Caltabiano, M.; Pagano, M.; Pezzuto, V.; Loreto, C.; Palestro, G. Detection of vascular endothelial growth factor/vascular permeability factor in periapical lesions. J. Endod. 2003, 29, 180-183. [CrossRef] [PubMed]

144. Zhang, Q.; Wang, D.; Kundumani-Sridharan, V.; Gadiparthi, L.; Johnson, D.A.; Tigyi, G.J.; Rao, G.N. PLD1-dependent PKC $\gamma$ activation downstream to Src is essential for the development of pathologic retinal neovascularization. Blood J. Am. Soc. Hematol. 2010, 116, 1377-1385. [CrossRef] [PubMed] 
145. Mäkinen, T.; Veikkola, T.; Mustjoki, S.; Karpanen, T.; Catimel, B.; Nice, E.C.; Wise, L.; Mercer, A.; Kowalski, H.; Kerjaschki, D. Isolated lymphatic endothelial cells transduce growth, survival and migratory signals via the VEGF-C/D receptor VEGFR-3. EMBO J. 2001, 20, 4762-4773. [CrossRef] [PubMed]

146. Salameh, A.; Galvagni, F.; Bardelli, M.; Bussolino, F.; Oliviero, S. Direct recruitment of CRK and GRB2 to VEGFR-3 induces proliferation, migration, and survival of endothelial cells through the activation of ERK, AKT, and JNK pathways. Blood 2005, 106, 3423-3431. [CrossRef]

147. Zhang, Q.; Wang, D.; Singh, N.K.; Kundumani-Sridharan, V.; Gadiparthi, L.; Rao, C.M.; Rao, G.N. Activation of cytosolic phospholipase A2 downstream of the Src-phospholipase D1 (PLD1)-protein kinase C $\gamma$ (PKC $\gamma$ ) signaling axis is required for hypoxia-induced pathological retinal angiogenesis. J. Biol. Chem. 2011, 286, 22489-22498. [CrossRef]

148. Wong, H.-K.; Shimizu, A.; Kirkpatrick, N.D.; Garkavtsev, I.; Chan, A.W.; di Tomaso, E.; Klagsbrun, M.; Jain, R.K. Merlin/NF2 Regulates Angiogenesis in Schwannomas through a Rac1/Semaphorin 3F-Dependent Mechanism. Neoplasia 2012, 14, 84-94. [CrossRef]

149. Stepanova, O.; Krylov, A.; Lioudyno, V.; Kisseleva, E. Gene expression for VEGF-A, VEGF-C, and their receptors in murine lymphocytes and macrophages. Biochemistry 2007, 72, 1194-1198. [CrossRef]

150. Hah, Y.-S.; Jun, J.-S.; Lee, S.-G.; Park, B.-W.; Kim, D.R.; Kim, U.-K.; Kim, J.-R.; Byun, J.-H. Vascular endothelial growth factor stimulates osteoblastic differentiation of cultured human periosteal-derived cells expressing vascular endothelial growth factor receptors. Mol. Biol. Rep. 2011, 38, 1443-1450. [CrossRef]

151. Bletsa, A.; Virtej, A.; Berggreen, E. Vascular endothelial growth factors and receptors are up-regulated during development of apical periodontitis. J. Endod. 2012, 38, 628-635. [CrossRef] [PubMed]

152. Basu, A.; Hoerning, A.; Datta, D.; Edelbauer, M.; Stack, M.P.; Calzadilla, K.; Pal, S.; Briscoe, D.M. Cutting edge: Vascular endothelial growth factor-mediated signaling in human CD45RO+ CD4+ T cells promotes Akt and ERK activation and costimulates IFN-gamma production. J. Immunol. 2010, 184, 545-549. [CrossRef] [PubMed]

153. Shin, J.Y.; Yoon, I.H.; Kim, J.S.; Kim, B.; Park, C.G. Vascular endothelial growth factor-induced chemotaxis and IL-10 from T cells. Cell Immunol. 2009, 256, 72-78. [CrossRef] [PubMed]

154. Weber, S.C.; Rheinlaender, C.; Sarioglu, N.; Peiser, C.; Rüdiger, M.; Obladen, M.; Koehne, P.S. The expression of VEGF and its receptors in the human ductus arteriosus. Pediatric Res. 2008, 64, 340-345. [CrossRef] [PubMed]

155. Chen, X.; Wang, Z.; Duan, N.; Zhu, G.; Schwarz, E.M.; Xie, C. Osteoblast-osteoclast interactions. Connect. Tissue Res. 2018, 59, 99-107. [CrossRef] [PubMed]

156. Aldridge, S.; Lennard, T.; Williams, J.; Birch, M. Vascular endothelial growth factor acts as an osteolytic factor in breast cancer metastases to bone. Br. J. Cancer 2005, 92, 1531-1537. [CrossRef] [PubMed]

157. Yang, Q.; McHugh, K.P.; Patntirapong, S.; Gu, X.; Wunderlich, L.; Hauschka, P.V. VEGF enhancement of osteoclast survival and bone resorption involves VEGF receptor-2 signaling and $\beta 3$-integrin. Matrix Biol. 2008, 27, 589-599. [CrossRef]

158. Sorsa, T.; Gursoy, U.K.; Nwhator, S.; Hernandez, M.; Tervahartiala, T.; Leppilahti, J.; Gursoy, M.; Könönen, E.; Emingil, G.; Pussinen, P.J.; et al. Analysis of matrix metalloproteinases, especially MMP-8, in gingival creviclular fluid, mouthrinse and saliva for monitoring periodontal diseases. Periodontol. 2000 2016, 70, 142-163. [CrossRef]

159. Baeza, M.; Garrido, M.; Hernández-Ríos, P.; Dezerega, A.; García-Sesnich, J.; Strauss, F.; Aitken, J.P.; Lesaffre, E.; Vanbelle, S.; Gamonal, J.; et al. Diagnostic accuracy for apical and chronic periodontitis biomarkers in gingival crevicular fluid: An exploratory study. J. Clin. Periodontol. 2016, 43, 34-45. [CrossRef]

160. Padma, R.; Sreedhara, A.; Indeevar, P.; Sarkar, I.; Kumar, C.S. Vascular endothelial growth factor levels in gingival crevicular fluid before and after periodontal therapy. J. Clin. Diagn. Res. 2014, 8, ZC75-ZC79. [CrossRef]

161. Pannicker, J.J.; Mehta, D.S. Effects of scaling and root planing on gingival crevicular fluid vascular endothelial growth factor level in chronic periodontitis patients with and without diabetes mellitus: A clinicobiochemical study. J. Indian Soc. Periodontol. 2016, 20, 244-248. [CrossRef] [PubMed]

162. Zani, S.R.; Moss, K.; Shibli, J.A.; Teixeira, E.R.; de Oliveira Mairink, R.; Onuma, T.; Feres, M.; Teles, R.P. Peri-implant crevicular fluid biomarkers as discriminants of peri-implant health and disease. J. Clin. Periodontol. 2016, 43, 825-832. [CrossRef] [PubMed]

163. Belmar, M.J.; Pabst, C.; Martínez, B.; Hernández, M. Gelatinolytic activity in gingival crevicular fluid from teeth with periapical lesions. Oral Surg. Oral Med. Oral Pathol. Oral Radiol. Endod. 2008, 105, 801-806. [CrossRef] [PubMed]

164. Sanz, I.; Alonso, B.; Carasol, M.; Herrera, D.; Sanz, M. Nonsurgical Treatment of Periodontitis. J. Evid. Based Dent. Pract. 2012, 12, 76-86. [CrossRef]

165. Bhavsar, I.; Miller, C.S.; Ebersole, J.L.; Dawson III, D.R.; Thompson, K.L.; Al-Sabbagh, M. Biological response to peri-implantitis treatment. J. Periodontal Res. 2019, 54, 720-728. [CrossRef] [PubMed]

166. Magnusson, I.; Walker, C.B. Refractory periodontitis or recurrence of disease. J. Clin. Periodontol. 1996, $23,289-292$. [CrossRef] [PubMed]

167. Narayanan, L.L.; Vaishnavi, C. Endodontic microbiology. J. Conserv. Dent. 2010, 13, 233-239. [CrossRef]

168. Kojima, K.; Inamoto, K.; Nagamatsu, K.; Hara, A.; Nakata, K.; Morita, I.; Nakagaki, H.; Nakamura, H. Success rate of endodontic treatment of teeth with vital and nonvital pulps. A meta-analysis. Oral Surg. Oral Med. Oral Pathol. Oral Radiol. Endod. 2004, 97, 95-99. [CrossRef]

169. Ohshima, M.; Yamaguchi, Y.; Ambe, K.; Horie, M.; Saito, A.; Nagase, T.; Nakashima, K.; Ohki, H.; Kawai, T.; Abiko, Y.; et al. Fibroblast VEGF-receptor 1 expression as molecular target in periodontitis. J. Clin. Periodontol. 2016, 43, 128-137. [CrossRef] 
170. Virtej, A.; Papadakou, P.; Sasaki, H.; Bletsa, A.; Berggreen, E. VEGFR-2 reduces while combined VEGFR-2 and -3 signaling increases inflammation in apical periodontitis. J. Oral Microbiol. 2016, 8, 32433. [CrossRef]

171. Menezes, R.; Garlet, T.P.; Letra, A.; Bramante, C.M.; Campanelli, A.P.; de Cássia Figueira, R.; Sogayar, M.C.; Granjeiro, J.M.; Garlet, G.P. Differential patterns of receptor activator of nuclear factor kappa B ligand/osteoprotegerin expression in human periapical granulomas: Possible association with progressive or stable nature of the lesions. J. Endod. 2008, 34, 932-938. [CrossRef] [PubMed]

172. Yokogami, K.; Yamashita, S.; Takeshima, H. Hypoxia-induced decreases in SOCS3 increase STAT3 activation and upregulate VEGF gene expression. Brain Tumor Pathol. 2013, 30, 135-143. [CrossRef] [PubMed]

173. Ribatti, D. The crucial role of vascular permeability factor/vascular endothelial growth factor in angiogenesis: A historical review. Br. J. Haematol. 2005, 128, 303-309. [CrossRef] [PubMed]

174. Ogilvie, C.M.; Lu, C.; Marcucio, R.; Lee, M.; Thompson, Z.; Hu, D.; Helms, J.A.; Miclau, T. Vascular endothelial growth factor improves bone repair in a murine nonunion model. Iowa Orthop. J. 2012, 32, 90-94. 